\title{
NHC Core Pincer Ligands Exhibiting Two Anionic Coordinating Extremities
}

\author{
Rachid Taakili and Yves Canac*D \\ LCC-CNRS, Université de Toulouse, CNRS, 31077 Toulouse, France; rachid.taakili@lcc-toulouse.fr \\ * Correspondence: yves.canac@lcc-toulouse.fr
}

Academic Editor: Vito Lippolis

Received: 20 April 2020; Accepted: 6 May 2020; Published: 9 May 2020

\begin{abstract}
The chemistry of NHC core pincer ligands of $\mathrm{LX}_{2}$ type bearing two pending arms, identical or not, whose coordinating center is anionic in nature, is here reviewed. In this family, the negative charge of the coordinating atoms can be brought either by a carbon atom via a phosphonium ylide $\left(\mathrm{R}_{3} \mathrm{P}^{+}-\mathrm{CR}_{2}{ }^{-}\right)$or by a heteroatom through amide $\left(\mathrm{R}_{2} \mathrm{~N}^{-}\right)$, oxide $\left(\mathrm{RO}^{-}\right)$, or thio(seleno)oxide $\left(\mathrm{RS}^{-}, \mathrm{RSe}^{-}\right)$ donor functionalities. Through selected examples, the synthetic methods, coordination properties, and applications of such tridentate systems are described. Particular emphasis is placed on the role of the donor ends in the chemical behavior of these species.
\end{abstract}

Keywords: carbon ligand; amide; negative charge; NHC; phosphonium ylide; oxide; pincer

\section{Introduction}

The term 'pincer' was introduced in 1989 by van Koten to refer to a tridentate ligand featuring a central anionic carbon atom coordinated through a covalent $\sigma$ bond and associated with two flanking arms that donate their electron lone pairs and force the metal center to adopt a meridional geometry [1]. This geometry has the main advantage of leaving an open coordination shell for any incoming molecule and of preventing undesired ligand redistribution processes [2-6]. The high stability, variability and activity of pincer ligands have made these species essential today in modern organometallic chemistry and homogeneous catalysis [7-9]. The first pincer system prepared by Shaw et al. in the late 1970s was based on an anionic carbon atom belonging to a central phenyl ring and bearing two neutral pendant phosphine donors, the so-called PCP pincer ligands [10]. This pioneering report was followed shortly after by the preparation of the NCN analogues by van Koten and Noltes [11]. From there, a wide variety of chemical motifs were designed, and the term 'pincer' was generally extended to any metallic complex adopting a meridional geometry whatever the bonding mode of the coordinating ends, as opposed to the facial coordination mode found in tripodal systems [12-14]. According to the Green formalism [15], although mono-anionic pincers ( $\mathrm{L}_{2} \mathrm{X}$-type) remain the most exemplified, other systems containing neutral ( $\mathrm{L}_{3}$-type), di- (LX $\mathrm{X}_{2}$-type), or tri-anionic $\left(\mathrm{X}_{3}\right.$-type) pincer frameworks were also developed allowing an efficient control of the metal coordination sphere and the stabilization of a broad range of metal centers with different oxidation states [16-22]. Among all pincer-type ligands, di-anionic representatives ( $\mathrm{LX}_{2}$-type) have been relatively little explored, and considering only the cases where the central donor moiety is neutral [23], three main sub-structures of this family have been reported over the years featuring either a pyridine [24-29], a carbodiphosphorane [30-32], or a N-heterocyclic carbene (NHC) [33,34]. The latter architecture B built from a neutral NHC core (2- $\mathrm{e}^{-}$donor (L-type)) and two anionic peripheral groups (1-e ${ }^{-}$donor (X-type) $)$is formally characterized by an opposite bonding mode to that encountered in the Shaw's prototype A derived from a central anionic aryl group (1- $\mathrm{e}^{-}$donor $(X-$ type $)$ and two neutral donor moieties (2-e $\mathrm{e}^{-}$donor (L-type)) (Scheme 1). In both structures, in addition to the 
thermodynamically favored chelate effect, the association of coordinating extremities of different nature extends naturally the scope of accessible metal fragments, but more generally of all centers having a Lewis acidic character. According to HSAB theory (hard soft acid base) [35,36], combining a soft NHC with two harder anionic groups must inevitably afford metallic complexes with unique properties, as is the case with systems B. For instance, a different bonding mode is anticipated with a high degree of covalency in the NHC-metal bond and a more marked ionic character between the negatively charged atoms and the metal center. It follows that anionic functionalized NHC ligands generally prefer to coordinate with electropositive metals, the anionic arms acting as a real anchor counterbalancing the natural tendency of the NHC to dissociate from the metal [37-41]. With late transition metals, an opposite behavior is expected with a possible lability of the anionic donor extremities [42-44]. All of these electronic criteria, combined with geometric parameters, govern the reactivity vs stability of these pincers, thus making each of them a unique system.<smiles>C1CC2[AlH]CCC2[Al]1</smiles>

\section{A}<smiles>[X][M]1=CCCCC1</smiles>

$\mathrm{L}=$ neutral donor

$\mathrm{X}=$ anionic donor

$M=$ metal fragment

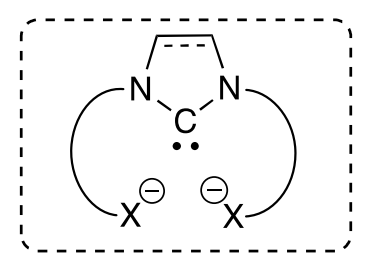

B $\quad \mathrm{X}=\mathrm{C}, \mathrm{N}, \mathrm{O}, \mathrm{S}, \mathrm{Se}$

Scheme 1. Representation of the $\mathrm{XL}_{2}$ prototype pincer $\mathbf{A}$ and $\mathrm{LX}_{2}$ pincers $\mathbf{B}$ of interest.

This review aims to account for this class of $\mathrm{LX}_{2}$-type pincer ligands $\mathbf{B}$ where the central NHC is $\mathrm{N}$-substituted by two side arms bearing identical or different anionic coordinating atoms, and which remains to this day underdeveloped compared to other families of pincer ligands. Through selected examples, the preparation methods, coordination properties, and applications of NHC core pincers exhibiting amide, oxide, thio(seleno)oxide, and phosphonium ylide donor extremities, which belong to this class of ligands, will be thus presented (Scheme 2).

a) Coordinating $\mathrm{O}, \mathrm{O}-$ atoms

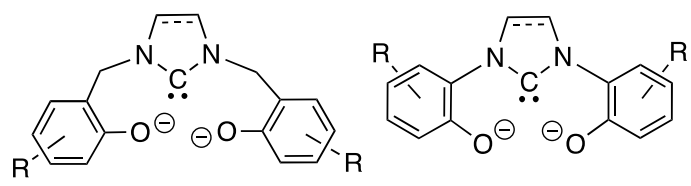<smiles></smiles><smiles></smiles>

b) Coordinating S,S- and Se,Se- atoms<smiles>[R]N=C([O-])n1ccn(/C([O-])=N\[R])c1=O</smiles><smiles>O=C1N(c2ccccc2S)CCN1c1ccccc1S</smiles>

c) Coordinating $\mathrm{N}, \mathrm{N}-$ atoms<smiles></smiles><smiles></smiles>

d) Coordinating C,C- atoms i e) Coordinating N,O- atoms

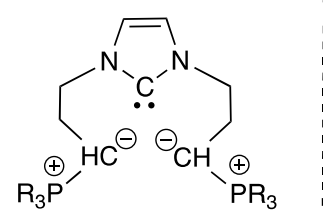<smiles>[R]Nc1ccccc1N1CCN(c2ccccc2[O-])C1=O</smiles><smiles>[R]N=C([S-])N1CCN(C(=[X])NCCCOS(=O)[O-])C(=O)N1</smiles>

g) Coordinating $\mathrm{C}, \mathrm{O}-$ atoms<smiles>[R5]C(C)Cn1ccn(-c2ccccc2[O-])c1=O</smiles>

Scheme 2. Representation of the general structure of known pincer structures of type $\mathbf{B}$ based on a central N-heterocyclic carbene (NHC) and two peripheral anionic coordinating atoms being identical or not. 


\section{NHC Core Pincer Ligands of $\mathrm{LX}_{2}$-Type}

\subsection{Based on Two Identical Side Arms}

\subsubsection{With Two Coordinating O- Atoms}

The first representatives of the family were reported by Kawaguchi et al. from the 1,3-bis(4,6-di-tert-butyl-2-hydroxybenzyl) imidazolium bromide 1 prepared in $60 \%$ yield via sequential $\mathrm{N}$-alkylation of imidazole with 2-bromomethyl-4,6-di-tert-butylphenol. By reacting the imidazolium salt 1 with $\mathrm{TiCl}_{4}(\mathrm{THF})_{2}$ in the presence of $\mathrm{NaN}\left(\mathrm{SiMe}_{3}\right)_{2}$, the bis(aryloxide) $\mathrm{NHC} \mathrm{Ti}(\mathrm{IV})$ pincer complex 2 was formed in 74\% yield (Scheme 3) [45]. An X-ray diffraction analysis confirms the meridional coordination mode of the NHC where the pseudo-octahedral geometry adopted by the Ti(IV) center is completed by a THF molecule and two chlorine atoms in mutual cis position. Using the same protocol, the $\mathrm{Zr}(\mathrm{IV})$ analogue 3 was prepared but with a lower yield (20\%) since it was obtained as a mixture with the corresponding homoleptic bis(NHC) $\mathrm{Zr}$ complex isolated in 38\% yield [46]. It should be mentioned that although the latter complex could be synthetized in $84 \%$ yield by the reaction of $\mathrm{ZrCl}_{4}(\mathrm{THF})_{2}$ with two equivalents of ligand, attempts to prepare complex 3 in a better yield failed. The larger ionic radius of $\mathrm{Zr}$ with respect to $\mathrm{Ti}$ was proposed to explain the more favorable formation of the bis(NHC) complex in the case of Zr. Both pincer complexes $\mathbf{2}$ and $\mathbf{3}$ could be converted to their alkyl derivatives via chloride displacement upon addition of Grignard reagents. For example, the chloro ligands in complexes $\mathbf{2}-\mathbf{3}$ could be substituted using 2 equivalents of $\mathrm{PhCH}_{2} \mathrm{MgCl}$ to form the corresponding dialkyl pincer complexes. Whatever the series, the benzyl complexes display a distorted trigonal bipyramidal geometry with a meridional coordination of the NHC.
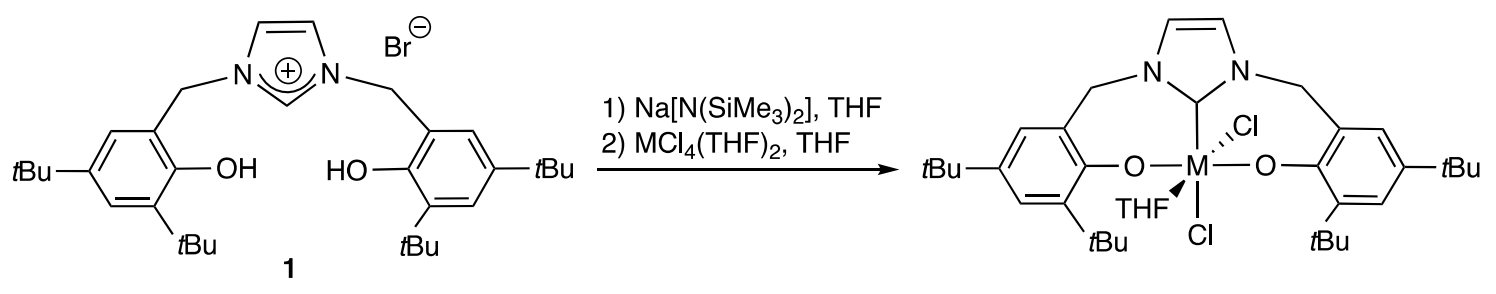

2: $\mathrm{M}=\mathrm{Ti}, 74 \%$ 3: $\mathrm{M}=\mathrm{Zr}, 20 \%$

Scheme 3. Preparation of group 4 pincer complexes 2-3 $(\mathrm{M}=\mathrm{Ti}, \mathrm{Zr})$ featuring a bis(aryloxide) NHC ligand from the imidazolium salt $\mathbf{1}[45,46]$.

Another striking fact concerns the dibromide analogue of complex 2, which, upon reduction with an equivalent of $\mathrm{LiBEt}_{3} \mathrm{H}$, led to the formation of a rare Ti(III) complex exhibiting a distorted octahedral geometry and where the coordination sphere around the metal is completed by the pincer ligand occupying meridional positions, two THF molecules in mutual trans position and a bromide co-ligand [47]. Following this, dinuclear complexes [48] and macrocyclic structures of the same tridentate ligand with group 4 metals were also reported by the same authors [49]. These metallic systems as well as the Ti(IV) pincer complex 2 showed significant catalytic activity for the polymerization of ethylene.

Based on the same flanking donor arms but with a central saturated six-membered NHC, rare earth pincer complexes $(\mathrm{Nd}, \mathrm{Y}, \mathrm{Sm})$ were prepared, fully characterized, and applied in the polymerization of $n$-hexyl isocyanate [50]. The polymer formed showed very high molecular weight and narrow molecular weight distribution. It was also demonstrated that the catalytic activity depends on the radius of rare earth metal, solvent, polymerization temperature, and the ligand structure. The saturated NHC moiety was in particular found to play a critical role in the initiation step of the polymerization process.

More rigid representatives of the same family were prepared via a different route, which consists of the elimination of alcohols from imidazolium salts. For instance, Ti(IV) complexes 5 and 6 were quantitatively formed by the reaction of the imidazolium salt 4 with $\mathrm{TiCl}(\mathrm{O} i \mathrm{Pr})_{3}$ and $\mathrm{Ti}(\mathrm{OiPr})_{4}$ 
precursors, respectively (Scheme 4) [51]. Deduced from a solid state analysis, complexes 5 and $\mathbf{6}$ exhibit a slightly distorted octahedral geometry with the bis(aryloxide) NHC ligand coordinated in a meridional manner. The NHC Ti(IV) complex 6 was shown to readily initiate the ring-opening polymerization of rac-lactide in a controlled fashion without the NHC a priori playing any role in the catalytic transformation. Related pincer complexes were obtained using the same protocol in the $\mathrm{Zr}(\mathrm{IV})$ and $\mathrm{Hf}(\mathrm{IV})$ series [52]. Despite lower yields, amine elimination was also found to be a possible route to afford such pincer complexes. The reaction of salt 4 with $\mathrm{M}\left(\mathrm{NMe}_{2}\right)_{4}(\mathrm{M}=\mathrm{Ti}, \mathrm{Zr})$ thus afforded the corresponding bis(phenoxy) NHC amido complexes.

Homoleptic bis-ligated NHC complexes could be also synthetized in high yields by reacting the imidazolium salt 4 with half of an equivalent of $\mathrm{MCl}_{4}$ complexes $(\mathrm{M}=\mathrm{Ti}, \mathrm{Zr}, \mathrm{Hf})$ in the presence of $\mathrm{Et}_{3} \mathrm{~N}$ [53]. In all complexes, the metal atom adopts a distorted octahedral geometry with the two NHCs located in trans position one from each other. These three NHC pincer complexes were described to be redox-active and, in the case of $\mathrm{Zr}$ and $\mathrm{Hf}$ derivatives, to present luminescent properties, constituting the first examples of emissive non-metallocene group 4 metal complexes. It must be mentioned that tetravalent Ti(IV) complexes bearing the same pincer ligand were found to be active and selective for the copolymerization of cyclohexene oxide with $\mathrm{CO}_{2}$ [54].

In the $\mathrm{Zr}$ series, toluene elimination was observed from the imidazolium salt 4 by using $\mathrm{Zr}\left(\mathrm{CH}_{2} \mathrm{Ph}\right)_{4}$ as a metal precursor leading to the corresponding chlorobenzyl NHC pincer complex 7 in quantitative yield (Scheme 4) [55]. However, while this complex is stable in non-coordinating solvents, in the presence of THF the quantitative formation of the unexpected Zr-THF adduct 8 as a single isomer was observed. The complex 8 is characterized by the presence of a heptacoordinate $\mathrm{Zr}$ center featuring an $O, N, C, N, O-$ pentadentate trianionic ligand. The formation of 8 was rationalized through a Lewis base assisted benzyl migration from the $\mathrm{Zr}$ atom to the carbenic center. This unusual benzyl migration was also observed with other group 4 metals (Ti, Hf) [56]. More recently, the reversibility of this benzyl migration was demonstrated by the addition of $\mathrm{PMe}_{3}$ to a bis(phenolate) benzylimidazolylidene(dibenzyl)zirconium complex and then abstraction of the coordinated $\mathrm{PMe}_{3}$ on the $\mathrm{Zr}$ complex formed with a $\mathrm{Ni}(0)$ complex [57].<smiles>CC(C)(C)c1cc(N2CCN(c3cc(C(C)(C)C)cc(C(C)(C)C)c3O)C2)c(O)c(C(C)(C)C)c1</smiles>

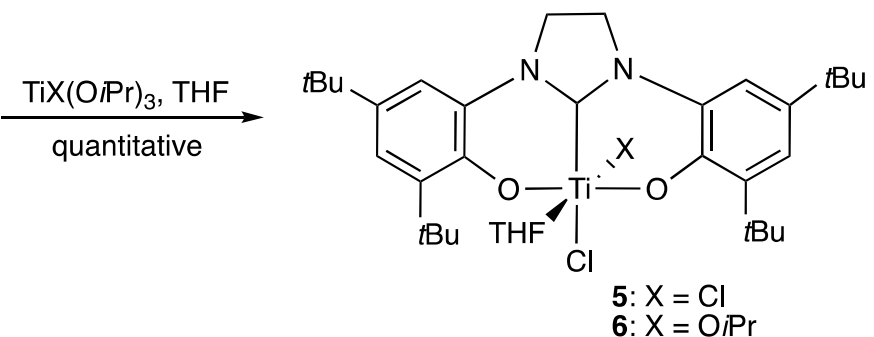<smiles></smiles><smiles>CC(C)(C)c1cc2c(c(C(C)(C)C)c1)ON1CCN2C(F)(Cl)c2c1cc(C(C)(C)C)cc2C(C)(C)C</smiles>

Scheme 4. Preparation of Ti(IV) and Zr(IV) pincer complexes 5-7 featuring a more rigid bis(aryloxide) NHC ligand from the imidazolium salt 4 , and unexpected rearrangement to the benzyl complex $\mathbf{8}[51,52,55]$.

Bis(aryloxide) NHC pincer ligands were successfully coordinated to a wide variety of metal centers, such as metals of groups 5 (V) [58], 6 (Mo) [59], 7 (Mn) [58], 9 (Ir [60], Co [61,62]), 10 (Ni, Pd, Pt) [63], and 13 (Al) [64]. More precisely from the imidazolium salt 4, high oxidation sate $\mathrm{V}(\mathrm{V})$ and $\mathrm{Mn}(\mathrm{III})$ metal complexes were readily prepared using triisopropoxyvanadium $(\mathrm{V})$ oxide $\left[(i \mathrm{PrO})_{3} \mathrm{~V}=\mathrm{O}\right]$ and 
manganese(III) acetylacetonate [Mn(aca) 3 ] precursors, respectively [58]. Al(III) complexes supported by such a dianionic NHC pincer ligand were obtained via various synthetic methods [64]. A possible route involved first, via alcohol elimination, the formation of the zwitterionic bis(phenolate) imidazolinium complex 9 featuring a four-coordinate tetrahedral Al(III) center $O, O$ - chelated by the two phenolate extremities (Scheme 5). The latter was then readily converted to the pincer NHC Al(III) complex 10 upon reaction with an equivalent of LDA. The dimeric nature of $\mathbf{1 0}$ is indicated by an X-ray diffraction analysis where the two $\mathrm{Al}$ centers are supported by a $\mathrm{O}, \mathrm{C}, \mathrm{O}$ - coordinated $\mathrm{NHC}$ bis(phenolate) ligand and connected to one another via $\mu$-O bridging Al-OiPr groups. Both Al centers display a slightly distorted trigonal bipyramidal geometry with a meridional coordination of the bis(phenolate) NHC ligand. Moreover, the pincer Al complex 10 was reported to efficiently polymerize rac-lactive and trimethylene carbonate in a highly controlled fashion for the production of narrow disperse materials with catalytic performance in the range of conventional group 13 based ROP catalysts.

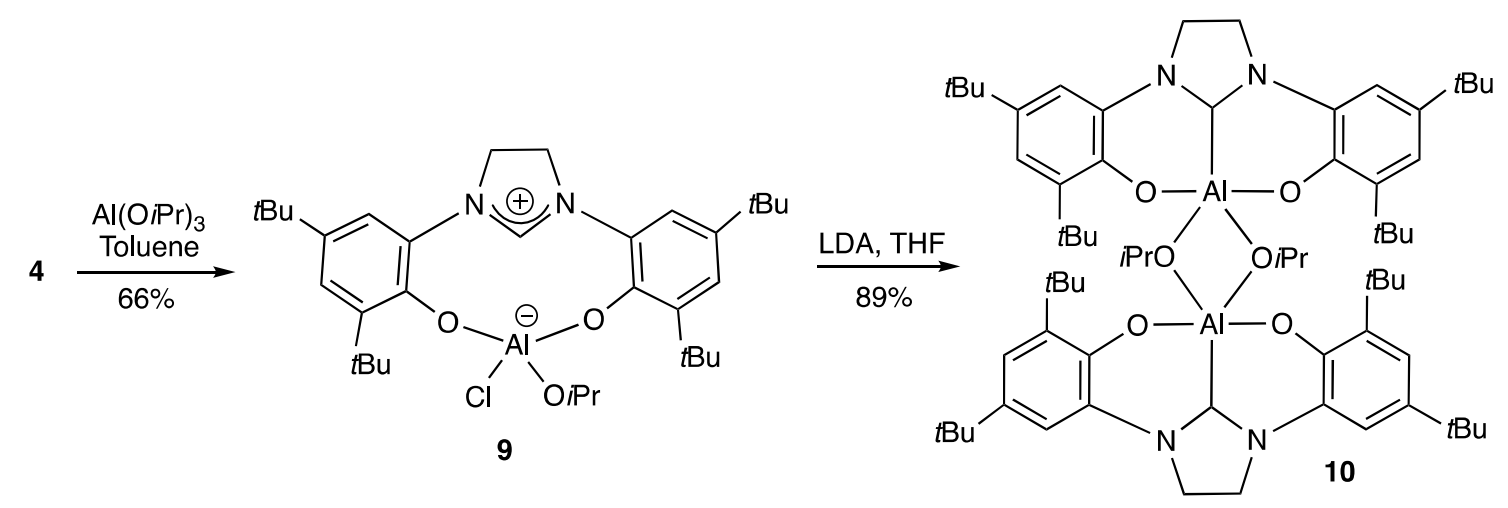

Scheme 5. Preparation of the dimeric Al(III) complex 10 featuring a more rigid bis(aryloxide) NHC ligand from the imidazolium salt 4 [64].

To accommodate heavy metal centers, the introduction of a benzimidazol-2-ylidene core was also considered, on the assumption that the presence of a $\pi$-conjugated system over the three six-membered aromatic rings should provide additional stabilization to the metal center. High-valent $\mathrm{NHC} \mathrm{Mo(VI)}$ complexes featuring a $\mathrm{O}, \mathrm{C}, \mathrm{O}$ - benzimidazolylidene pincer ligand were prepared, as illustrated with the complex 12 isolated in $75 \%$ yield by addition of (DME) $\mathrm{MoO}_{2} \mathrm{Cl}_{2}$ in $\mathrm{THF}$ to the benzimidazolium precursor 11 in the presence of $\mathrm{Et}_{3} \mathrm{~N}$ (Scheme 6, top) [59]. In the solid state, the dioxo complex 12 was found to crystallize following two different arrangements, namely a dimeric structure with two six-coordinate $\mathrm{Mo}(\mathrm{VI})$ atoms in a strongly distorted octahedral environment and a monomeric form with the five-coordinate $\mathrm{Mo}(\mathrm{VI})$ center lying in between a square pyramidal and a trigonal bipyramidal geometry. The dioxo complex 12, which represents a rare example of five-coordinated Mo(VI) complex, was found to be stable toward air and moisture in the solid state and in solution. The pre-ligand $\mathbf{1 1}$ was also reported to stabilize oxo-imido and bis(imido) Mo(VI) pincer complexes.

A series of group 10 metal complexes, 13-15, was prepared in good yield (66-79\%) when the same precursor 11 was treated with one equivalent of $\mathrm{MCl}_{2}(\mathrm{M}=\mathrm{Ni}, \mathrm{Pd}, \mathrm{Pt})$ in the presence of an excess of potassium carbonate in pyridine at $100{ }^{\circ} \mathrm{C}$ (Scheme 6, bottom) [63]. This one-pot procedure was also successfully applied in the imidazolylidene series. Imposed by the tridentate NHC, these complexes adopt a distorted square-planar geometry. DFT studies performed on Pd and Pt representatives indicated that the HOMO is centered on the metal and the aryloxide fragment while the LUMO involves mainly the pyridine co-ligand. Based on these findings, optical properties were studied evidencing the absence of luminescence at room temperature but in the case of Pt complexes the presence of an emission band in the green region of the visible spectrum at $77 \mathrm{~K}$, which was attributed to a long-lived triplet-manifold excited state featuring MLLCT character [63]. 


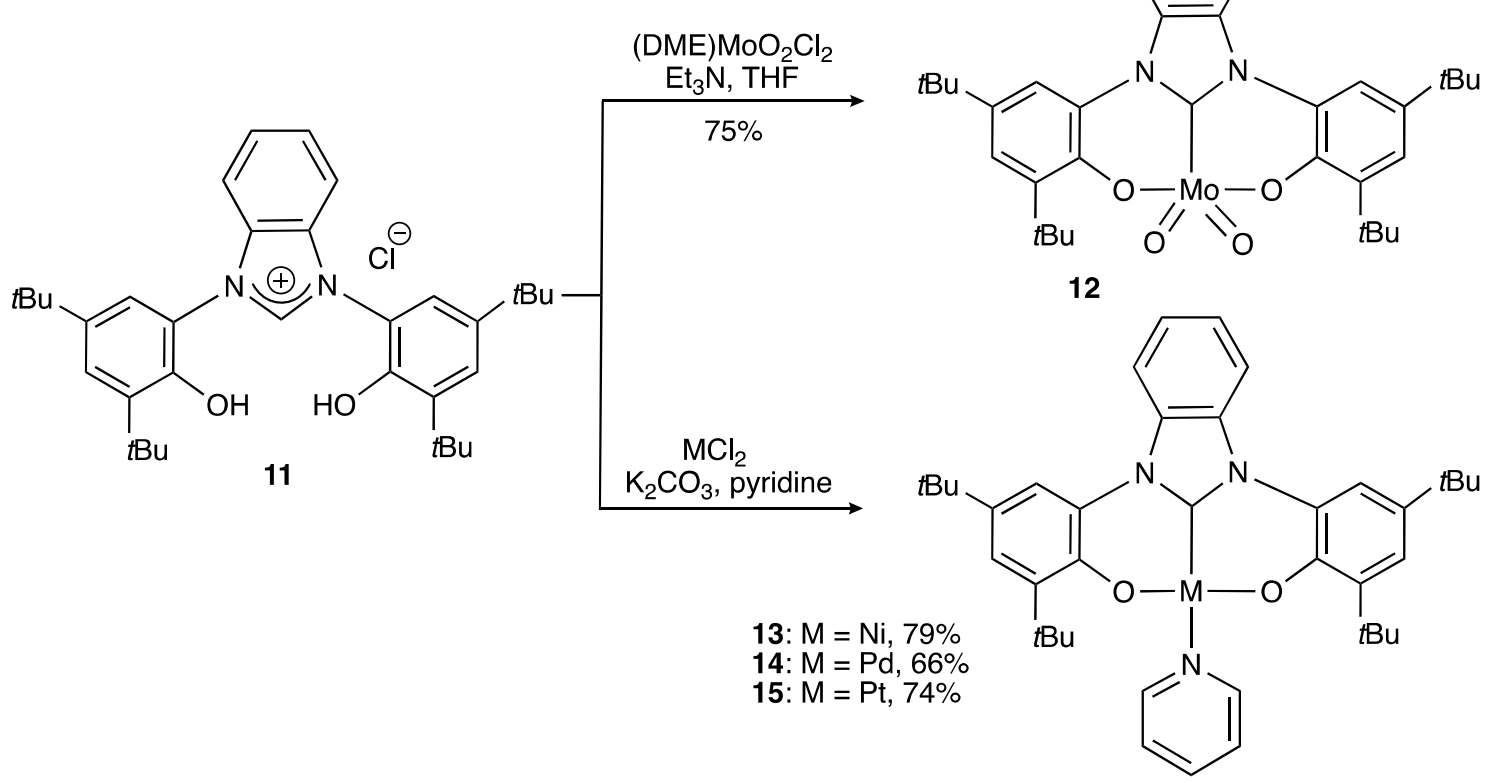

Scheme 6. Preparation of metal complexes 12-15 (M = Mo, Ni, Pd, Pt) from the benzimidazolium salt $11[59,63]$.

In the Co series, the trifluoromethylation of (hetero)arenes was reported, thanks to the thermally stable pincer $\mathrm{Co}(\mathrm{III})$ complex 16, which is able under light exposure to release a $\mathrm{CF}_{3}$ radical (Scheme 7) [62]. This result represents an elegant strategy to activate strong $\mathrm{M}-\mathrm{CF}_{3}$ bonds for the functionalization of small molecules. From a synthetic point of view, the Co(III) complex $\mathbf{1 6}$ was formed by oxidation of the corresponding four-coordinate $\mathrm{Co}(\mathrm{II})$ complex using $\mathrm{AgCF}_{3}$ in $\mathrm{MeCN}$. An $\mathrm{X}$-ray diffraction analysis of $\mathbf{1 6}$ indicates that the $\mathrm{CF}_{3}$ group is orthogonal to the $\mathrm{O}, \mathrm{C}, \mathrm{O}$ - $\mathrm{Co}$ plane with a short $\mathrm{Co}-\mathrm{CF}_{3}$ bond in favor of a high degree of covalency. The complex 16 appeared to be diamagnetic well described as a low-spin Co(III) center stabilized by a closed-shell dianionic bis(phenolate) NHC core pincer ligand.<smiles>[R][R]1cccc([X])c1</smiles><smiles></smiles>

Scheme 7. Photoinduced trifluoromethylation of (hetero)arenes by the pincer Co(III) complex 16 [62].

Very recently, the first bis(phenolate) mesoionic carbene was reported by Hohloch et al. following a ten-step procedure and was shown to be a valuable ligand for the preparation of various heteroleptic early transition metal pincer complexes (group 4 to group 6) (Scheme 8) [65]. The triazolium salt 17, which can be prepared on a multi-gram scale, was obtained by reacting phenyl substrates bearing alkyne and azide functionalities under classical click conditions. Prior to N-methylation, the two alcohol functions were protected in the presence of bis(trimethylsilyl)acetamide (BSA). Treatment with $\mathrm{MeOH}$ followed by salt metathesis with tetraethylammonium chloride afforded finally the pre-ligand $\mathbf{1 7}$ 
in $51 \%$ overall yield. From the latter, rare examples of $\mathrm{Ti}, \mathrm{Mo}$, and $\mathrm{Nb}$ imido complexes were prepared, as illustrated with the $\mathrm{Nb}$ complex 18 isolated in $62 \%$ yield. The $\mathrm{Nb}$ atom in 18 resides in a distorted octahedral environment where the coordination sphere is completed by the $\mathrm{O}, \mathrm{C}, \mathrm{O}$ - pincer ligand and imido, chloro, and pyridine co-ligands. Comparison of the electrochemical properties of these carbenic complexes with more classical bis(phenolate) NHC complexes conclude that, as expected, triazolylidenes are more difficult to oxidize than imidazolinylidene-based systems.

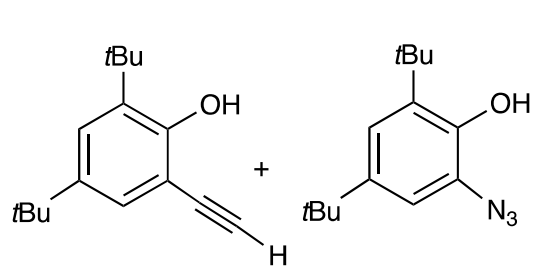

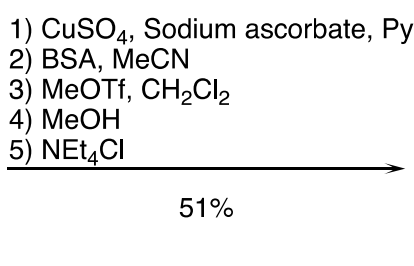<smiles></smiles>

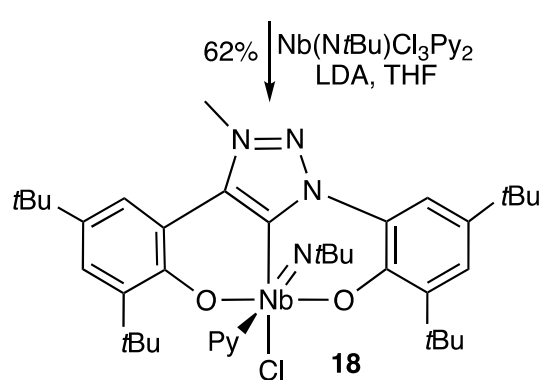

Scheme 8. Preparation of the $\mathrm{Nb}$ complex 18 featuring a bis(phenolate) mesoionic carbene ligand [65].

After the development of various bis(aryloxy) NHC core systems, bis(alkoxy) analogues were naturally considered. For such purpose and based on preliminary studies on bidentate systems [66,67], the introduction of electron-withdrawing $\mathrm{CF}_{3}$ groups was envisaged to decrease the acidity of the alcohol hydrogen atoms. Indeed, the stability of fluoroalkoxy carbenes has been reported, in particular the reluctance of the alkoxy fragment not to react with the electrophilic imidazolium center as may be the case with more basic alkoxides [68]. Under phase-transfer catalysis, the imidazolium salt 19 as a stable zwitterion was thus prepared through a sequential method by reacting $1 H$-imidazole with hexafluoroisobutylene oxide (Scheme 9) [69]. It is noteworthy that the salt 19 could be obtained in excellent yield $(94 \%)$ via a one-pot procedure without isolating the imidazole intermediate. This methodology was extended to 3,4-disubstituted imidazole and triazole derivatives. Treatment of 19 with two equivalents of $t \mathrm{BuOK}$ generated the corresponding free carbene, which was observed to be relatively stable in solution. Addition of $\left[\mathrm{NiCl}_{2}\left(\mathrm{PPh}_{3}\right)_{2}\right]$ to this carbene resulted in the formation of the NHC pincer 20 and the bis(NHC) complex 21 in a 2/1 ratio. While an X-ray diffraction analysis of 20 confirmed the square-planar geometry around the $\mathrm{Ni}$ (II) center with the meridional coordination of the bis(alkoxy) NHC that of 21 indicated that two alkoxy groups of the same NHC are bound to Ni and the two hydroxyl groups from the other NHC are hydrogen-bonded to the adjacent oxygen atoms. 


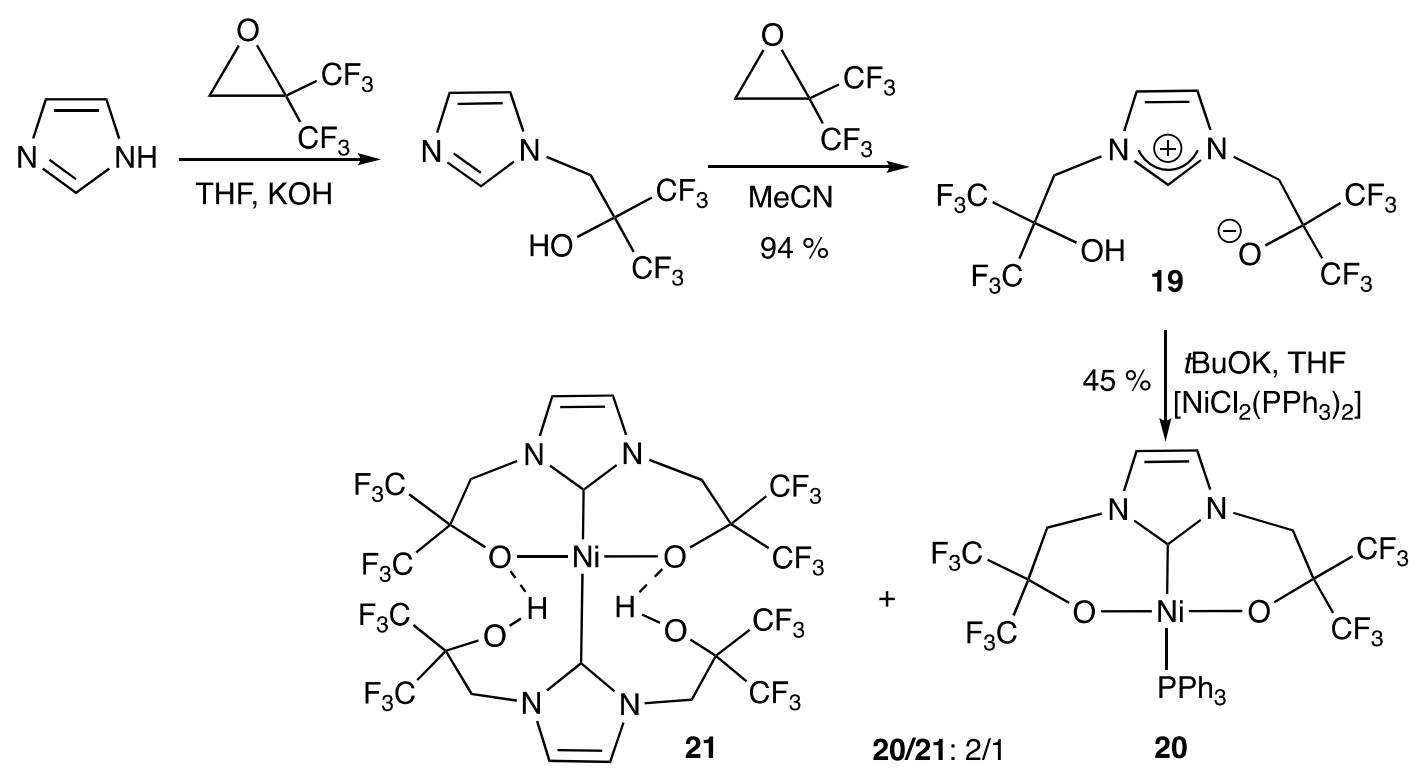

Scheme 9. Preparation of bis(alkoxy) NHC Ni(II) complexes 20 and 21 from $1 H$-imidazole [69].

\subsubsection{With Two Coordinating S- (or Se) Atoms}

Bis(thiolate) NHC core complexes were actually reported before their oxygenated analogues. The first complexes were obtained by reacting $\mathrm{Pd}\left(\mathrm{PPh}_{3}\right)_{4}$ and $\mathrm{RhCl}\left(\mathrm{PPh}_{3}\right)_{3}$ with tetraazapentalene derivatives 22, the latter exhibiting unique reactivity due to the presence of hypervalent sulfur (Scheme 10) [70]. In both cases, the formation of Pd(II) and Rh(III) complexes 23 and 24 was accompanied by the release of triphenylphosphine sulfide. It is noteworthy that, depending on the nature of the amine substituents (R), the bis(thiolate) NHC complexes were isolated as a mixture with their isostructural complexes containing an unsymmetrical amido, NHC, thiolate pincer ligand, knowing that more hindered $\mathrm{R}$ substituents, disadvantage a priori the latter form. The best ratios in favor of the $S, C, S$ - pincer complexes 23 and 24 were observed with small $p$-Cl- and $p$ - $\mathrm{MeOC}_{6} \mathrm{H}_{4}$ amine substituents with yields between $86 \%$ and $99 \%$. The complexes based on a $N, C, S$ - ligand were generally found to be less stable than their analogues exhibiting the symmetrical $S, C, S-$ ligand. In a Pd complex of type 23 bearing N-Me groups, an X-ray diffraction analysis was performed confirming the square planar geometry around the $\mathrm{Pd}(\mathrm{II})$ center surrounded by two sulfur, one phosphorus, and a carbenic carbon atom. This Pd complex was found to be very stable in organic solvents under air. For Rh(III) complexes of type $\mathbf{2 4}$, the octahedral geometry of the metal center with two phosphine ligands located in trans position was deduced on the basis of a solid state analysis performed in the case of a Rh complex featuring the hybrid $S C N$ - pincer ligand. Following the same strategy, a diselenato version of $\mathbf{2 2}$ based on a five-membered saturated NHC was prepared by the same authors and coordinated with different metal centers such as $\mathrm{Pd}\left(\mathrm{PPh}_{3}\right)_{4}, \mathrm{Pt}\left(\mathrm{PPh}_{3}\right)_{4}$, and $\mathrm{RhCl}\left(\mathrm{PPh}_{3}\right)_{3}$, affording corresponding $\mathrm{Se}, \mathrm{C}, \mathrm{Se}$ - pincer complexes. [71,72]

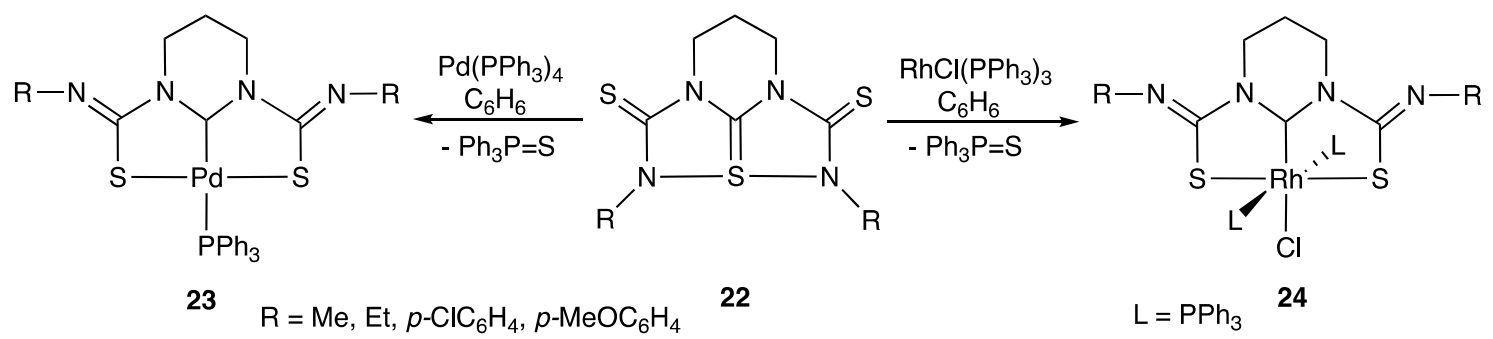

Scheme 10. Preparation of tridentate bis(thiolate) NHC Pd(II) and Rh(III) complexes 23 and 24 from tetraazapentalene derivatives 22 [70]. 
Another representative of the family was described by Sellmann et al. who observed the unexpected formation of bis(thiolate) NHC Ni(II) pincer complexes 27 upon dissociation of the dimeric complex 26 by addition of different metallic salts (KCN, LiMe, NaSPh) (Scheme 11) [73]. X-ray structure determinations confirmed the square planar geometry around the metal center with a characteristic propeller-like twist resulting from positioning the phenyl rings above and below the coordination plane. If the pincer complexes 27 exhibit remarkable thermal stability, in the presence of Brönsted acids, the regeneration of dimer 26 was noticed.

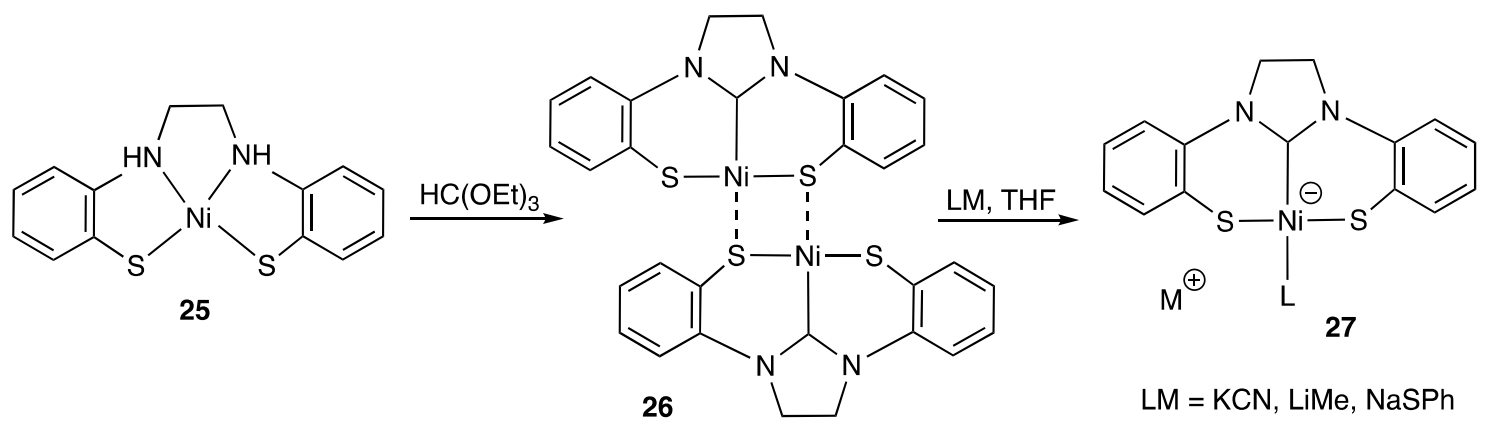

Scheme 11. Preparation of bis(thiolate) NHC Ni(II) pincer complexes 27 through dissociation of the dimeric precursor 26 [73].

\subsubsection{With Two Coordinating N- Atoms}

The first bis(amido) NHC pincer complex was described by Fryzuk et al. in 2004 in the $\mathrm{Zr}(\mathrm{IV})$ series [74]. The corresponding pre-ligand, namely the bis(amine) imidazolium salt 28 (Ar = Tol) was synthetized by the reduction of a bis(amide) imidazolium salt using borane-dimethylsulfide. Later, in order to introduce larger $\mathrm{N}$-aryl groups $(\mathrm{Ar}=\mathrm{Mes}, \mathrm{Xy})$, an alternative route was developed consisting of melting the appropriate N-substituted imidazole with a $\beta$-chloroethylarylamine [75]. Whatever the preparation method, imidazolium salts 28 were treated with $\mathrm{KN}\left(\mathrm{SiMe}_{3}\right)_{2}$ to give in good yield the stable free NHCs substituted by two amine donor arms. The latter reacted cleanly with $\mathrm{M}\left(\mathrm{NMe}_{2}\right)_{4}$ complexes $(\mathrm{M}=\mathrm{Zr}, \mathrm{Hf})$, providing a convenient entry to $N, C, N$ - group 4 pincer complexes (Scheme 12). The dimethylamido co-ligands could be readily removed by adding an excess of chlorotrimethylsilane, affording the corresponding dichloride adducts which were then converted into dialkyl complexes by treatment with Grignard reagents. In the case of a Hf complex of type $\mathbf{3 0}$ bearing two isobutyl groups, an X-ray diffraction analysis evidences a distorted trigonal bipyramidal geometry around the metal atom with the two amido moieties in pseudo-trans position [75]. It should be noted that Hf dialkyl complexes are more thermally stable than $\mathrm{Zr}$ representatives, with the exception of the Hf diethyl complex which undergoes $\beta$-hydrogen transfer and subsequent $\mathrm{C}-\mathrm{H}$ bond activation with the neighboring N-Mes substituent to afford a cyclometalled complex [75]. The Hf dialkyl complexes were also shown to insert carbon monoxide and isocyanides to give the related $\eta^{2}$ - acyl and $\eta^{2}$ - iminoacyl derivatives. After activation with $\left[\mathrm{Ph}_{3} \mathrm{C}, \mathrm{B}\left(\mathrm{C}_{6} \mathrm{~F}_{5}\right)_{4}\right]$, the $\mathrm{Zr}$ dimethyl complex showed moderate catalytic activity for ethylene polymerization.
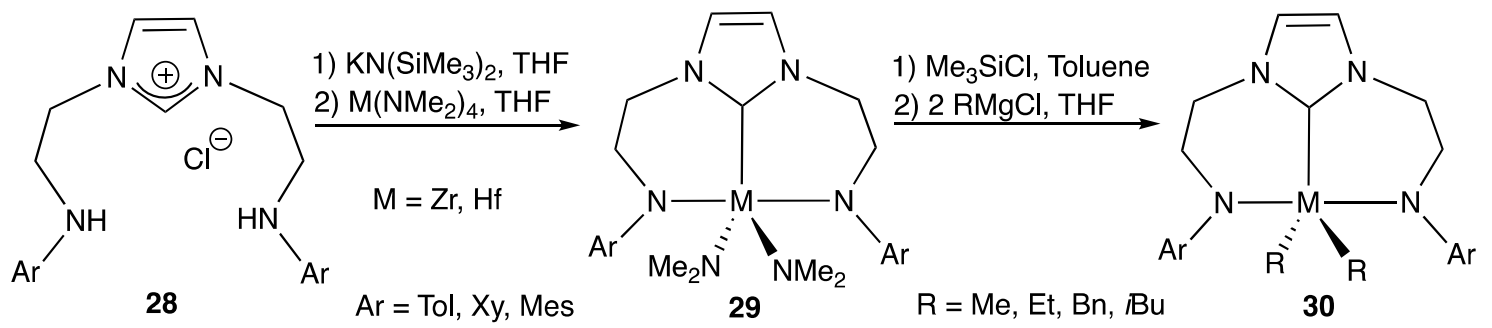

Scheme 12. Preparation of bis(amido) NHC pincer complexes $(\mathrm{M}=\mathrm{Zr}, \mathrm{Hf}) 29$ and 30 from the imidazolium salt $28[74,75]$. 
From the same pre-ligand, bis(amido) NHC tantalum pincer complexes were also reported [76]. However, to reach such systems, the formation of the dilithiated diamido NHC ligand 32 prepared by addition of 2 equivalents of BuLi to the free carbene 31 was a prerequisite. Indeed, from the free carbene 31, only the formation of bidentate amido NHC Ta complexes were observed, the remaining amine arm being reluctant to coordinate the metal center. By contrast, the metathesis reaction of 32 in the presence of various $\mathrm{TaCl}_{\mathrm{X}}\left(\mathrm{NMe}_{2}\right)_{5-\mathrm{x}}$ precursors proceeded under mild conditions and in good yield to afford the desired pincer complexes, as illustrated with complex 33 (Scheme 13, top). However, attempts to synthetize trialkyl derivatives following this methodology were not successful, yielding instead metallaziridines, as demonstrated with the formation of $N, C, C, N-\mathrm{NHC} \mathrm{Ta}(\mathrm{V})$ complexes 34 (Scheme 13, bottom). An X-ray diffraction analysis of one of these representatives (with $\mathrm{R}=\mathrm{Np}$ ) emphasizes the facial orientation of the activated $\mathrm{C}-\mathrm{H}$ bond and the distorted pseudo trigonal bipyramidal geometry around the Ta center. DFT calculations confirm that such cyclometallated species formed by the endocyclic C-H activation of one of the amido arms are thermodynamically favored over the targeted trialkyl derivatives.

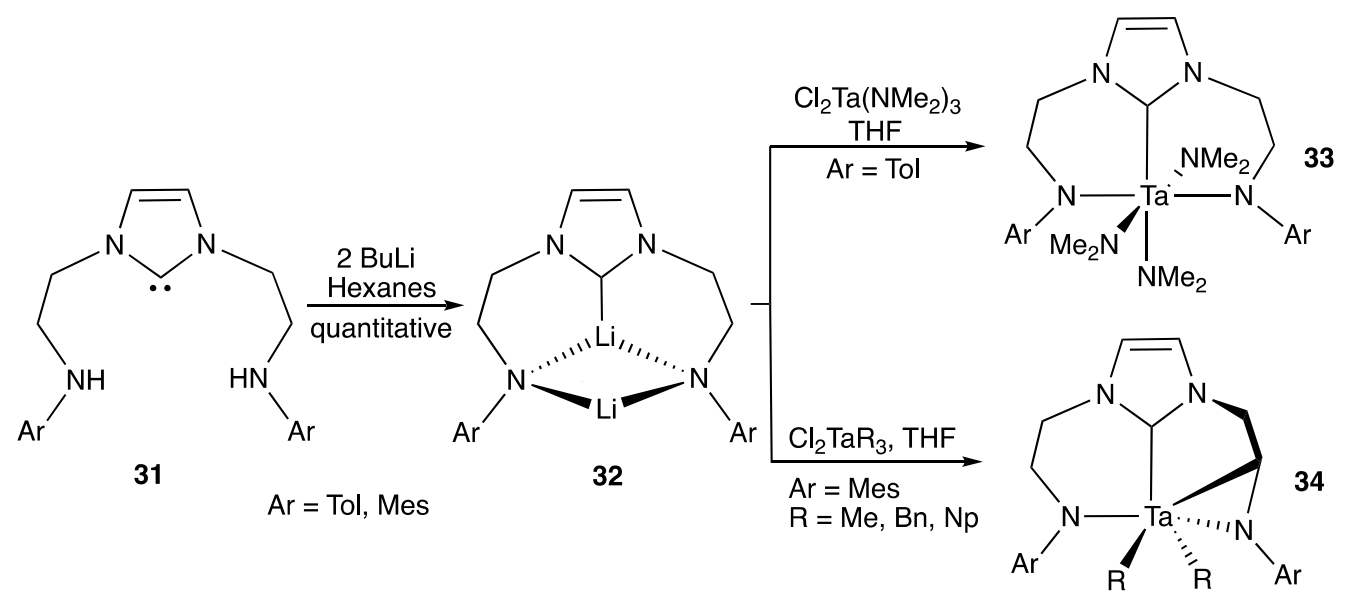

Scheme 13. Preparation of bis(amido) NHC Ta(V) complexes 33 and 34 from the free NHC 31 [76].

Bis(amido) NHC ligands were also coordinated to group 10 metal centers. The Pd(II) complex 36 was prepared from the tridentate imidazolium salt 35 exhibiting two side amide arms and $\mathrm{PdCl}_{2}$ in the presence of the $\mathrm{K}_{2} \mathrm{CO}_{3}$ /pyridine system (Scheme 14) [77]. This square planar pincer Pd complex isolated in $77 \%$ yield showed significant catalytic activity in Suzuki coupling reactions of aryl bromides with phenylboronic acid, although less than corresponding monodentate NHC Pd complexes bearing a pendant neutral amine arm. This difference was attributed to the too strongly anionic amido coordinating ends, which do not allow in the case of $\mathbf{3 6}$ the release of vacant sites during the catalytic process. The dissociation of the neutral NHC moiety is expected to be more favorable with electropositive early transition metal centers.
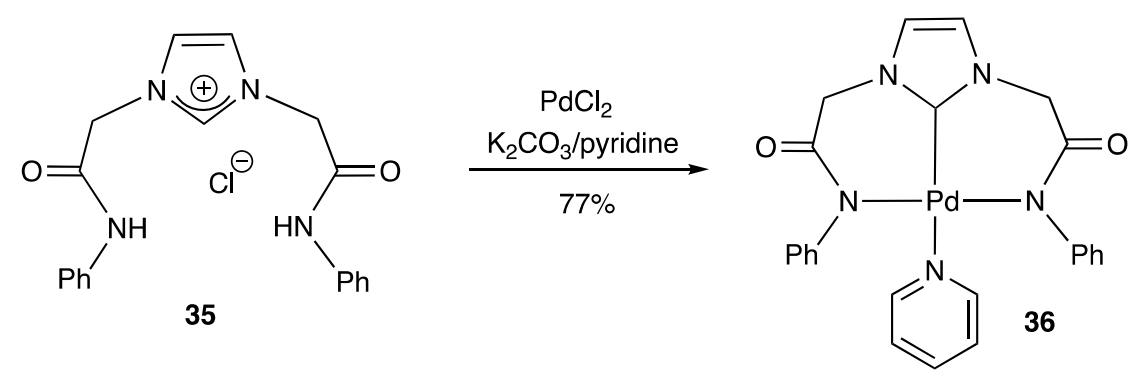

Scheme 14. Preparation of the bis(amido) NHC Pd(II) pincer complex 36 from the imidazolium salt 35 [77]. 


\subsubsection{With Two Coordinating C- Atoms}

Phosphonium ylides are globally neutral in their free state, characterized by an almost planar carbanion stabilized by an adjacent tetrahedral phosphonium center. In their coordination state, phosphonium ylides act exclusively as $\eta^{1}$ - carbon centered ligands, rather than as $\eta^{2}-C=P$ ligands [78], and can therefore be considered locally as anionic carbon ligands [79]. This chemical description means that phosphonium ylides like NHCs behave as strong $\sigma$-donor carbon ligands while differing in their bonding mode (NHC, $2 \mathrm{e}^{-}$donor ( $\mathrm{L}$ type); $\mathrm{P}^{+}$-ylide, $1 \mathrm{e}^{-}$donor ( $\mathrm{X}$ type)) [80,81]. Following preliminary reports in the field aimed at developing ylide-based metal complexes [82-85], NHC and phosphonium ylide donor moieties were recently associated by a $C_{3}$-propyl bridge in the bi- [86], tetradente [87], and in the pincer series forming very electron-rich complexes [88], thanks to the design of a general synthetic strategy [89].

A new family of pincer $\mathrm{Pd}(\mathrm{II})$ complexes bearing an electron-rich $C, C, C-\mathrm{NHC}$, diphosphonium bis(ylide) ligand was indeed prepared from the imidazolium salt 37 featuring two phosphonium side chains obtained through the dual $\mathrm{N}$-functionalization of $1 \mathrm{H}$-imidazole by (3-bromopropyl)triphenylphosphonium bromide (Scheme 15) [88]. Due to a difference in acidity between the cationic moieties, the imidazolium salt 37 was sequentially coordinated to Pd(II) centers leading first to the NHC Pd complex 38 and then to the ortho-metallated Pd complex 39. Protonation of the latter afforded the NHC, diphosphonium bis(ylide) pincer Pd(II) complex 40 as a mixture of meso- and $\mathrm{dl}$-diastereomers ( $\mathrm{de}=50 \%$ ). The pincer complex 40 isolated in $94 \%$ yield appeared to be perfectly stable in air both in the solid state and in solution. The selectivity of C-coordination was rationalized on the basis of DFT calculations, indicating the quasi-degeneracy of the two diastereomeric forms. Thanks to its electronic properties, this NHC core pincer was shown to efficiently stabilize $\mathrm{Pd}(\mathrm{II})$ complexes bearing isocyanide $\mathbf{4 1}$ and carbonyl co-ligands $\mathbf{4 2}$, whose examples of this latter type remain rare due to easy $\mathrm{Pd}-\mathrm{CO}$ dissociation (Scheme 15). In the isocyanide case, an $\mathrm{X}$-ray diffraction analysis of both isomers was achieved showing that the $\mathrm{Pd}(\mathrm{II})$ atom is an integral part of two strongly distorted fused six-membered metallacycles and resides in a quasi-square planar environment with the two phosphonium ylides occupying mutually trans positions [88].

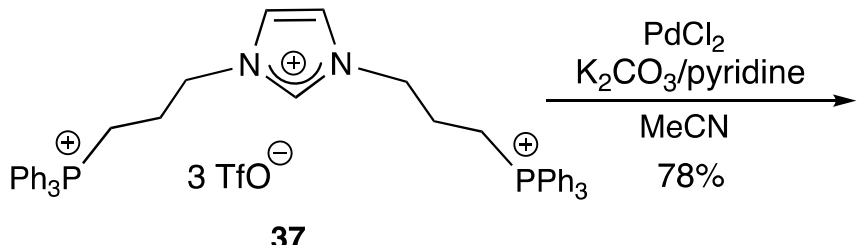

37
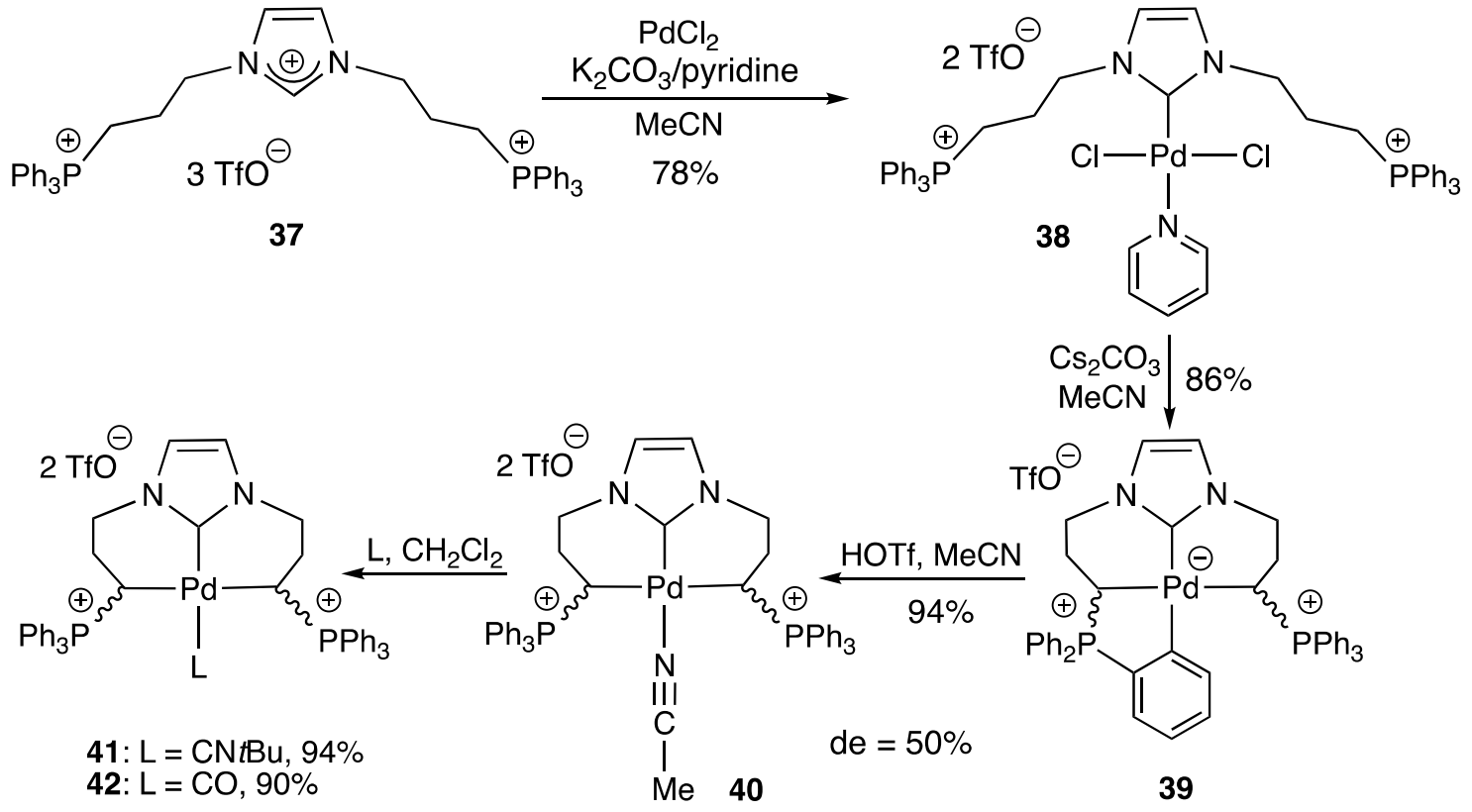

Scheme 15. Preparation of NHC, diphosphonium bis(ylide) Pd(II) pincer complexes $\mathbf{4 0 - 4 2}$ from the imidazolium salt 37 [88]. 
NHC core diphosphonium bis(ylide) Pd complexes $\mathbf{4 0 - 4 2}$ represent the sole examples of $\mathrm{LX}_{2}$-type pincer complexes where the metal center is bonded only with carbon atoms, in the present case being of different nature: one carbenic $\left(s p^{2}\right)$ and two ylidic $\left(s p^{3}\right)$ carbon atoms. Their availability combined with their stability should benefit catalytic processes requiring extremely electron-rich ligands.

\subsection{Based on Two Different Side Arms}

The interest in unsymmetrical pincer ligands has considerably increased in recent years since they can provide significantly different chemical donor extremities with a more or less pronounced hard/soft character, thus affording metal complexes with unprecedented properties. This may lead in particular to catalysts exhibiting unique reactivity and selectivity profiles. In this direction, NHC core pincers of $\mathrm{LX}_{2}$-type bearing two different side arms are rare and their synthesis represent an additional synthetic challenge because their formation requires the coordination of three different donors having their own chemical features at the same metallic center. For instance, the coordination of neutral and/or anionic donor ends possessing a wide range of basicity will have to take into account the relative acidity of each $\mathrm{H}$-atom in the corresponding conjugated acid precursors.

\subsubsection{With $\mathrm{N}, \mathrm{O}-$ Coordinating Atoms}

In the last decade, the preparation of the imidazolium salt 43 bearing pending amine and phenol arms was reported in four steps in 52\% overall yield from 2-( $\mathrm{N}$-mesitylamino) aniline [90]. However, while this cation appeared to be stable in the solid state, it was observed to quantitatively rearrange in solution to form the thermodynamically favored benzimidazolium salt 44 (Scheme 16) [91]. DFT calculations were performed to rationalize the mechanism of this unprecedented rearrangement. Despite its unstability, various attempts to coordinate the pre-ligand $\mathbf{4 3}$ were carried out with group 4 metals, all leading to unexpected species but not to the desired pincer complexes. It is worth mentioning the formation of the $\mathrm{Zr}(\mathrm{IV})$ complex 45, which was obtained when the precursor 43 was reacted with $\mathrm{ZrBn}_{4}$ and $\mathrm{BnMgCl}$ in toluene. The formation of $\mathbf{4 5}$ results formally from the migration of a benzyl group and a proton to the carbenic center, converting the heterocycle to an imidazolidine. The latter stands as a $\mathrm{Zr}(\mathrm{IV})$ complex where the metallic center interacts with a tetradentate $\mathrm{N}, \mathrm{N}, \mathrm{N}, \mathrm{O}-$ dianionic ligand featuring two X-type (amide and phenoxide) and two L-type (amine) donor moieties. Similar benzyl migration was already evidenced in $\mathrm{Zr}(\mathrm{IV})$ complexes supported by bis(phenoxy) NHC pincer ligands [55]. These surprising results tend to illustrate the difficulty of access to unsymmetrical pincer systems containing different coordinating ends.<smiles></smiles>

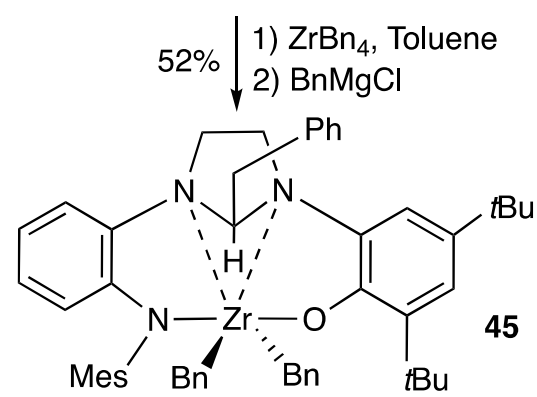

Scheme 16. Preparation of the tridentate $N, C, O$ - imidazolium salt 43 with corresponding thermal rearrangement to the benzimidazolium salt 44 and coordination to the $\mathrm{Zr}(\mathrm{IV})$ complex 45 [90,91]. 


\subsubsection{With $\mathrm{N}, \mathrm{S}$ - Coordinating Atoms}

The method developed to prepare $S, C, S$ - pincer complexes (see Scheme 10) also enabled the synthesis of unsymmetrical pincer complexes as illustrated with the formation of the $S, C, N-\mathrm{Pt}$ (II) 47 and Rh(III) 48 complexes. The difference lies in the nature of the tetraazapentalene substrates $\mathbf{4 6}$ where a thiocarbonyl function is replaced by a carbonyl group (Scheme 17) [92]. As demonstrated in the $\mathrm{Rh}(\mathrm{III})$ series, the substitution of both thiocarbonyls by two carbonyl groups does not lead, as one might have expected, to the formation of $N, C, N$ - pincers but to a bidentate $N, S$ - Rh complex [92].

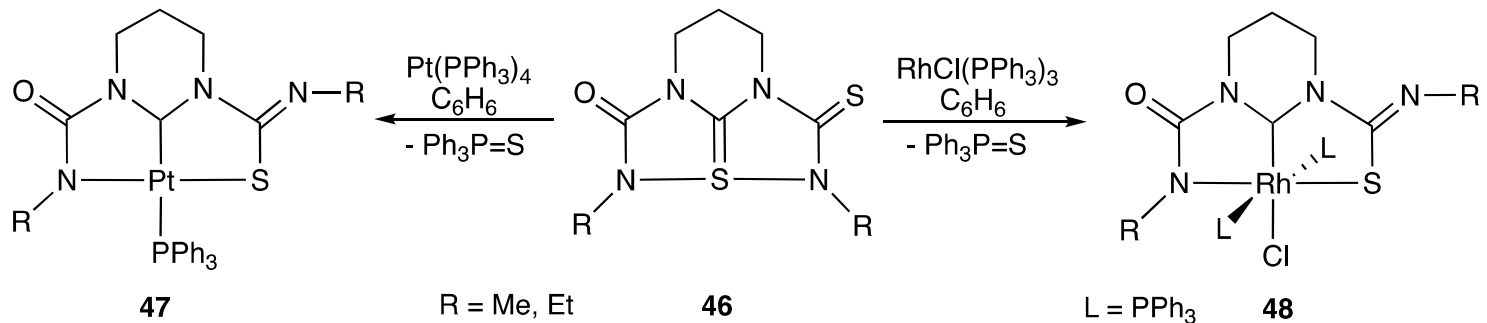

Scheme 17. Preparation of $S, C, N$ - pincer complexes $47(\mathrm{M}=\mathrm{Pt})$ and $48(\mathrm{M}=\mathrm{Rh})$ from unsymmetrical tetraazapentalenes 46 [92].

\subsubsection{With $\mathrm{C}, \mathrm{O}-$ Coordinating Atoms}

With the previous cases $47-48$, the Pd(II) complex 52 constitutes one of the very rare examples of NHC core pincer complex of $\mathrm{LX}_{2}$-type exhibiting two different peripheral coordinating extremities reported to date [93]. The latter, featuring pending phenolate and phosphonium ylide moieties, was readily obtained from the ortho-metallated Pd complex 51 in 94\% yield, thanks to the selective acid cleavage of a $\mathrm{C}_{\mathrm{ar}}-\mathrm{Pd}$ bond using HOTf in $\mathrm{MeCN}$ (Scheme 18). The highly strained zwitterionic $\mathrm{C}, \mathrm{C}, \mathrm{C}, \mathrm{O}-\mathrm{Pd}$ complex $\mathbf{5 1}$ was prepared through two distinct routes, either directly from the tridentate imidazolium salt 49 by adding $\mathrm{PdCl}_{2}$ in the presence of $\mathrm{Cs}_{2} \mathrm{CO}_{3}$ in $84 \%$ yield or in a two-step procedure via the NHC Pd pyridine adduct 50 in $64 \%$ overall yield. The pincer complex 52 was readily converted to its isocyanide analogue 53 by an exchange reaction at the Pd center. In this case, the formation of a $\mathrm{Pd}-\mathrm{CO}$ adduct was not experimentally observed, due probably to the too weak donor character of the $C, C, O$ - pincer ligand.

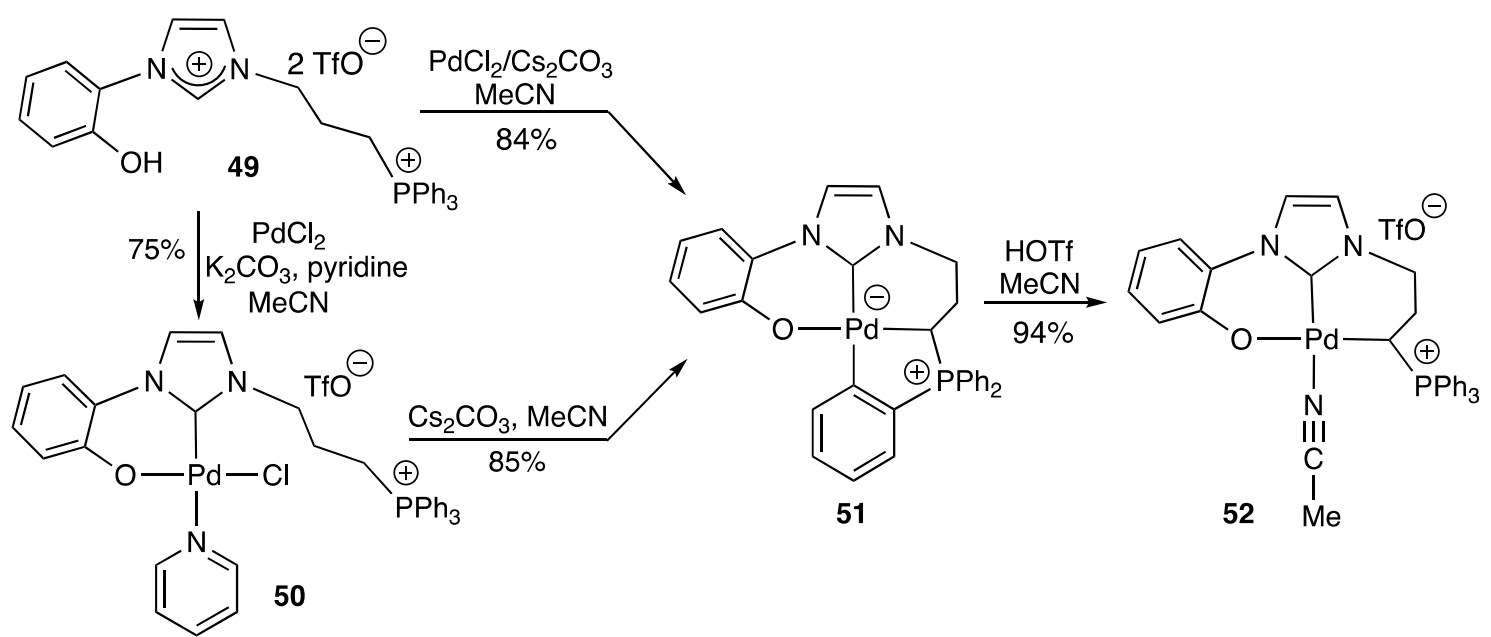

Scheme 18. Preparation of the $C, C, O$ - phenolate, NHC, phosphonium ylide pincer Pd(II) complex 52 from the imidazolium salt 49 following two different routes [93].

The overall donating character of the $\mathrm{C}, \mathrm{C}, \mathrm{O}$ - ligand of complex $\mathbf{5 2}$ was further analyzed on the basis of IR $v_{\mathrm{CO}}$ and $v_{\mathrm{CN}}$ stretching frequencies, oxidation potentials, and DFT calculations by 
comparison with isostructural phosphonium ylide-based pincer Pd complexes. Notably, the IR $v_{C N}$ frequency values of Pd complexes $53\left(2207 \mathrm{~cm}^{-1}\right)$ and $55\left(2206 \mathrm{~cm}^{-1}\right)$ indicate that the $C, C, O-\mathrm{NHC}$, phenolate, phosphonium ylide, and the $C, C, C$ - bis(NHC) phosphonium ylide have similar electronic properties. These IR values, which appear at higher frequency than that of the Pd-CNtBu complex 41 $\left(2194 \mathrm{~cm}^{-1}\right)$, bearing the $C, C, C$ - bis(ylide) NHC ligand lead to the conclusion that the substitution of a NHC or a phenolate for a phosphonium ylide increases significantly the donor character of corresponding pincer ligands (Scheme 19) [93]. The Pd-CO complex 42 only experimentally observed in the case of the bis(ylide) ligand is in perfect agreement with these findings. This trend was also found to be in line with previous studies performed on an isoelectronic series of C,C-chelating NHC, phosphonium ylide $\mathrm{Rh}(\mathrm{CO})_{2}$ complexes. [94,95]<smiles>CC1(P)C([Pb])CCN2C=CN3CCCCC321</smiles>

41: $\mathrm{L}=\mathrm{CN} t \mathrm{Bu}, v_{\mathrm{CN}}=2194$ 42: $L=C O, v_{C O}=2114$<smiles>O=C1CC([Pb])P2(I)(Oc3ccccc32)n2ccn21</smiles>

53: $\mathrm{L}=\mathrm{CNtBu}, v_{\mathrm{CN}}=2207$ 54: $L=C O$, not formed

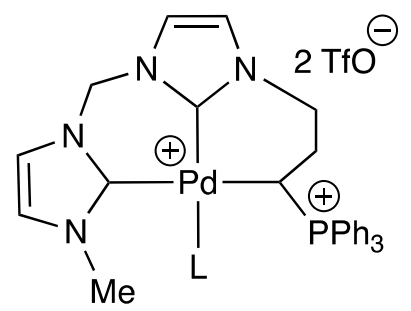

55: $\mathrm{L}=\mathrm{CNtBu}, v_{\mathrm{CN}}=2206$ 56: $L=C O$, not formed

Scheme 19. Experimental IR $v_{\mathrm{CO}}$ and $v_{\mathrm{CN}}$ stretching frequencies $\left(\mathrm{cm}^{-1}\right)$ for NHC core phosphonium ylide-based pincer $\mathrm{Pd}(\mathrm{II})$ complexes ( $\mathrm{L}=\mathrm{CN} t \mathrm{Bu}$ or $\mathrm{CO}$ ) [93].

The electronic properties of these phosphonium ylide-based pincer $\mathrm{Pd}(\mathrm{II})$ complexes were exploited in homogeneous catalysis for the Pd-catalyzed allylation of aldehydes. It was in particular observed that the Pd complex bearing the most donor pincer ligand, namely the NHC, bis(ylide), was the most active in this catalytic process [93].

\section{Conclusions and Perspectives}

In perpetual search for new ligands, those based on pincer architecture have a promising future, not only because of a structural diversity, which remains to be discovered, but also because of their many potential applications, especially in the fields of organometallic chemistry, homogeneous catalysis, and materials. In this large family, pincer ligands of $\mathrm{LX}_{2}$-type which position two anionic donor units on either side of a neutral central donor are less common and undoubtedly deserve to be more considered. Combining neutral with anionic donor extremities indeed offers several advantages such as the efficient coordination of a wide range of metal centers and the access to unusual oxidation states. For instance, anionic donors are more likely to bind early transition metals, while neutral ones generally prefer to coordinate late transition metals. In this category of pincer ligands, NHCs substituted by two anionic arms represent a promising family. The association of NHCs with anionic donors indeed makes it possible to stabilize but also to modulate the reactivity of various metal complexes across the periodic table. Independently of the two anionic arms, the nature of the central donor allows a fine adjustment of the electronic properties of the pincer structure since saturated, unsaturated, five- or six-membered NHCs, as well as mesoionic carbenes can be introduced. However, the preparation of such chelating systems generally represents a synthetic challenge in terms of coordination selectivity and choice of metal center in order to reach a good compromise between stability and reactivity. As pointed out in this review, the nature of the donors used in this family of pincer ligand remains very limited to date, and there is no doubt that the introduction of other donor functionalities should allow the development of new properties in the area of redox and photo-active systems but would also be beneficial for the activation of small molecules and for homogeneous catalysis. 
Author Contributions: R.T.: literature survey; Y.C.: conceptualization, writing, editing. All authors have read and agreed to the published version of the manuscript.

Funding: This research received no external funding.

Acknowledgments: The authors thank the Centre National de la Recherche Scientifique (CNRS) for financial support. R.T. is grateful to French MENESR for a PhD fellowship.

Conflicts of Interest: The authors declare no conflict of interest.

\section{References}

1. Van Koten, G. Tuning the reactivity of metals held in a rigid ligand environment. Pure Appl. Chem. 1989, 61, 1681-1694. [CrossRef]

2. Morales-Morales, D.; Jensen, C.G.M. The Chemistry of Pincer Compounds, 1st ed.; Elsevier Science: Amsterdam, The Netherlands, 2011.

3. Van Koten, G.; Milstein, D. Organometallic Pincer Chemistry; Van Koten, G., Milstein, D., Eds.; Springer: Berlin/Heidelberg, Germany, 2013; Volume 40, pp. 1-356.

4. Adams, G.M.; Weller, A.S. POP-type ligands: Variable coordination and hemilabile behaviour. Coord. Chem. Rev. 2018, 355, 150-172. [CrossRef]

5. Benito-Garagorri, D.; Kirchner, K. Modularly designed transition metal PNP and PCP pincer complexes based on aminophosphines: Synthesis and catalytic applications. Acc. Chem. Res. 2008, 41, 201-213. [CrossRef] [PubMed]

6. Roddick, D.M.; Zargarian, D. Pentacoordination for pincer and related tertendate coordination compounds: Revisiting structural properties and trends for $\mathrm{d}^{8}$ transition metal systems. Inorg. Chim. Acta 2014, 422, 251-264. [CrossRef]

7. Szabó, K.J.; Wendt, O.F. (Eds.) Pincer and Pincer-Type Complexes: Applications in Organic Synthesis and Catalysis; Willey-VCH: Weinheim, Germany, 2014.

8. Gunanathan, G.; Milstein, D. Bond activation and catalysis by ruthenium pincer complexes. Chem. Rev. 2014, 114, 12024-12087. [CrossRef]

9. Maser, L.; Vondung, L.; Langer, R. The ABC in pincer chemistry-from amine to borylene and carbon-based pincer ligands. Polyhedron 2018, 143, 28-42. [CrossRef]

10. Moulton, C.J.; Shaw, B.L. Transition metal-carbon bonds. Part XLII. Complexes of nickel, palladium, platinum, rhodium and iridium with the tridentate ligand 2,6-bis[(di-t-butylphosphino)methyl]phenyl. J. Chem. Soc. Dalton Trans. 1976, 11, 1020-1024. [CrossRef]

11. Van Koten, G.; Timmer, K.; Noltes, J.G.; Spek, A.L. A novel type of Pt-C interaction and a model for the final stage in reductive elimination processes involving $\mathrm{C}-\mathrm{C}$ coupling at $\mathrm{Pt}$; synthesis and molecular geometry of $\left[1, N, N^{\prime}-\eta\right.$-2,6-bis $\{$ (dimethylamino)methyl\}toluene]iodoplatinum(II) tetrafluoroborate. J. Chem. Soc. Chem. Commun. 1978, 6, 250-252. [CrossRef]

12. Parkin, G. The bioinorganic chemistry of zinc: Synthetic analogues of zinc enzymes that feature tripodal ligands. Chem. Commun. 2000, 20, 1971-1985. [CrossRef]

13. Blackman, A.G. Tripodal tetraamine ligands containing three pyridine units: The other polypyridyl ligands. Eur. J. Inorg. Chem. 2008, 2008, 2633-2647. [CrossRef]

14. Gamble, A.J.; Lynam, J.M.; Thatcher, R.J.; Walton, P.H.; Whitwood, A.C. Cis-1,3,5-triaminocyclohexane as a facially cappind ligand for ruthenium(II). Inorg. Chem. 2013, 52, 4517-4527. [CrossRef] [PubMed]

15. Green, M.L.H. A new approach for the formal classification of covalents compounds of the elements. J. Organomet. Chem. 1995, 500, 127-148. [CrossRef]

16. Pugh, D.; Danapoulos, A.A. Metal complexes with 'pincer'-type ligands incorporating N-heterocyclic carbene functionalities. Coord. Chem. Rev. 2007, 251, 610-641. [CrossRef]

17. Niu, J.L.; Hao, X.Q.; Gong, J.F.; Song, M.P. Symmetrical and unsymmetrical pincer complexes with group 10 metals: Synthesis via aryl C-H activation and some catalytic applications. Dalton Trans. 2011, 40, 5135-5150. [CrossRef] [PubMed]

18. O'Reilly, M.E.; Veige, A.S. Trianionic pincer and pincer-type metal complexes and catalysts. Chem. Soc. Rev. 2014, 43, 6325-6369. [CrossRef]

19. Deng, Q.H.; Melen, R.L.; Gade, L.H. Anionic chiral tridentate N-donor pincer ligands in asymmetric catalysis. Acc. Chem. Res. 2014, 47, 3162-3173. [CrossRef] 
20. Murugesan, S.; Kirchner, K. Non-precious metal complexes with an anionic PCP pincer architecture. Dalton Trans. 2016, 45, 416-439. [CrossRef]

21. Peris, E.; Crabtree, R.H. Key factors in pincer ligand design. Chem. Soc. Rev. 2018, 27, 1959-1968. [CrossRef]

22. Liu, J.K.; Gong, J.F.; Song, M.P. Chiral palladium pincer complexes for asymmetric catalytic reactions. Org. Biomol. Chem. 2019, 17, 6069-6098. [CrossRef]

23. Luconi, L.; Rossin, A.; Motta, A.; Tuci, G.; Giambastiani, G. Group IV organometallic compounds based on dianionic pincer ligands: Synthesis, characterization, and catalytic activity in intramolecular hydroamination reactions. Chem. Eur. J. 2013, 19, 4906-4921. [CrossRef]

24. Agapie, T.; Day, M.W.; Bercaw, J.E. Synthesis and reactivity of tantalum complexes supported by bidentate $\mathrm{X}_{2}$ and tridentate $\mathrm{LX}_{2}$ ligand with two phenolates linked to pyridine, thiophene, furan, and benzene connectors: Mechanistic studies of the formation of a tantalum benzylidene and insertion chemistry for tantalum-carbon bonds. Organometallics 2008, 27, 6123-6142.

25. Winston, M.S.; Bercaw, J.E. A novel bis(phosphido)pyridine $[\mathrm{PNP}]^{2-}$ pincer ligand and its potassium and bis(dimethylamido)zirconium(IV) complexes. Organometallics 2010, 29, 6408-6416. [CrossRef]

26. Lenton, T.N.; VanderVelde, D.G.; Bercaw, J.E. Synthesis of a bis(thiophenolate)pyridine ligand and its titanium, zirconium, and tantalum complexes. Organometallics 2012, 31, 7492-7499. [CrossRef]

27. Komiyama, Y.; Kuwabara, J.; Kanbara, T. Deprotonation-induced structural changes in SNS-pincer ruthenium complexes with secondary thioamide groups. Organometallics 2014, 33, 885-891. [CrossRef]

28. Suzuki, T.; Kajita, Y.; Masuda, H. Deprotonation/protonation-driven change of the $\sigma$-donor ability of a sulfur atom in iron(II) complexes with a thioamide SNS pincer type ligand. Dalton Trans. 2014, 43, 9732-9739. [CrossRef] [PubMed]

29. Islam, M.J.; Smith, M.D.; Peryshkov, D.V. Sterically encumbered dianionic dicarboranyl pincer ligand $\left(\mathrm{C}_{5} \mathrm{H}_{3} \mathrm{~N}\right)\left(\mathrm{C}_{2} \mathrm{~B}_{10} \mathrm{H}_{11}\right)_{2}$ and its $\mathrm{CNC}$ nickel(II) complex. J. Organomet. Chem. 2018, 867, 208-2013. [CrossRef]

30. Kubo, K.; Jones, N.D.; Ferguson, M.J.; McDonald, R.; Cavell, R.G. Chelate and pincer carbene complexes of rhodium and platinum derived from hexaphenylcarbodiphosphorane, $\mathrm{Ph}_{3}=\mathrm{C}=\mathrm{PPh}_{3}$. J. Am. Chem. Soc. 2005, 127, 5314-5315. [CrossRef]

31. Petz, W.; Neumüller, B. New platinum complexes with carbodiphosphorane as pincer ligand via ortho phenyl metallation. Polyhedron 2011, 30, 1779-1784. [CrossRef]

32. Kubo, K.; Okitsu, H.; Miwa, H.; Kume, S.; Cavell, R.G. Carbon(0)-bridged Pt/Ag dinuclear and tetranuclear complexes based on a cyclometalated pincer carbodiphosphorane platform. Organometallics 2017, 36, 266-274. [CrossRef]

33. Liddle, S.T.; Edworthy, I.S.; Arnold, P.L. Anionic tethered N-heterocyclic carbene chemistry. Chem. Soc. Rev. 2007, 36, 1732-1744. [CrossRef]

34. Zhang, D.; Zi, G. N-heterocyclic carbene (NHC) complexes of group 4 transition metals. Chem. Soc. Rev. 2015, 44, 1898-1921. [CrossRef] [PubMed]

35. Pearson, R.G. Antisymbiosis and the trans effect. Inorg. Chem. 1973, 12, 712-713. [CrossRef]

36. Pearson, R.G. Absolute electronegativity and hardness: Application to inorganic chemistry. Inorg. Chem. 1988, 27, 734-740. [CrossRef]

37. Arnold, P.L.; Liddle, S.T. F-block N-heterocyclic carbenes. Chem. Commun. 2006, 38, 3959-3971. [CrossRef] [PubMed]

38. Fliedel, C.; Schnee, G.; Avilés, T.; Dagorne, S. Group 13 metal (Al, Ga, In, Tl) complexes supported by heteroatom-bonded carbene ligands. Coord. Chem. Rev. 2014, 275, 63-86. [CrossRef]

39. Bellemin-Laponnaz, S.; Dagorne, S. Group 1 and 2 and early transition metal complexes bearing N-heterocyclic carbene ligands: Coordination chemistry, reactivity and applications. Chem. Rev. 2014, 114, 8747-8774. [CrossRef]

40. Hameury, S.; de Frémont, P.; Braunstein, P. Metal complexes with oxygen-functionalized NHC ligands: Synthesis and applications. Chem. Soc. Rev. 2017, 46, 632-733. [CrossRef]

41. Guérin, V.; Ménard, A.; Guernon, H.; Moutounet, O.; Legault, C.Y. From chelating to bridging ligands: $\mathrm{N}$-sulfonyliminoimidazolium ylides as precursors to anionic $\mathrm{N}$-heterocyclic carbene ligands. Organometallics 2019, 38, 409-416. [CrossRef]

42. Bartoszewicz, A.; Marcos, R.; Sahoo, S.; Inge, A.K.; Zou, X.; Martin-Matute, B. A highly active bifunctional iridium complex with an alcohol/alkoxide-tethered N-heterocyclic carbene for alkylation of amines with alcohols. Chem. Eur. J. 2012, 18, 14510-14519. [CrossRef] 
43. Pape, F.; Teichert, J.F. Dealing at arm's length: Catalysis with N-Heterocyclic carbene ligands bearing anionic tethers. Eur. J. Org. Chem. 2017, 2017, 4206-4229. [CrossRef]

44. Evans, K.J.; Campbell, C.L.; Haddow, M.F.; Luz, C.; Morton, P.A.; Mansell, S.M. Lithium complexes with bridging and terminal NHC ligands: The decisive influence of an anionic tether. Eur. J. Inorg. Chem. 2019, 2019, 4894-4901. [CrossRef]

45. Aihara, H.; Matsuo, T.; Kawaguchi, H. Titanium N-heterocyclic carbene complexes incorporating an imidazolium-linked bis(phenol). Chem. Commun. 2003, 17, 2204-2205. [CrossRef] [PubMed]

46. Zhang, D.; Aihara, H.; Watanabe, T.; Matsuo, T.; Kawaguchi, H. Zirconium complexes of the tridentate bis(aryloxide)- $N$-heterocyclic-carbene ligand: Chloride and alkyl functionalized derivatives. J. Organomet. Chem. 2007, 692, 234-242. [CrossRef]

47. Zhang, D.; Liu, N. Titanium complexes bearing bisaryloxy-N-heterocyclic carbenes: Synthesis, reactivity, and ethylene polymerization study. Organometallics 2009, 28, 499-505. [CrossRef]

48. Zhang, D. Dinuclear titanium(IV) complexes bearing phenoxide-tethered N-heterocyclic carbene ligands with cisoid conformation through control of hydrolysis. Eur. J. Inorg. Chem. 2007, 2007, 4839-4845. [CrossRef]

49. Zhang, D.; GengShi, G.; Wang, J.; Yue, Q.; Zheng, W.; Weng, L. Macrocyclic hexanuclear zirconium(IV) complex bearing a bisaryloxyl N-heterocyclic-carbene ligand: Synthesis, structure, and catalytic properties. Inorg. Chem. Commun. 2010, 13, 433-435. [CrossRef]

50. Zhang, M.; Zhang, J.; Ni, X.; Shen, Z. Bis(phenolate) N-heterocyclic carbene rare earth metal complexes: Synthesis, characterization and applications in the polymerization of $n$-hexyl isocyanate. RSC Adv. 2015, 5, 83295-83303. [CrossRef]

51. Romain, C.; Brelot, L.; Bellemin-Laponnaz, S.; Dagorne, S. Synthesis and structural characterization of a novel family of titanium complexes bearing a tridentate bis-phenolate-N-heterocyclic carbene dianionic ligand and their use in the controlled ROP of rac-lactide. Organometallics 2010, 29, 1191-1198. [CrossRef]

52. Dagorne, S.; Bellemin-Laponnaz, S.; Romain, C. Neutral and cationic N-heterocyclic carbene zirconium and hafnium benzyl complexes: Highly regioselective oligomerization of 1-hexene with a preference for trimer formation. Organometallics 2013, 32, 2736-2743. [CrossRef]

53. Romain, C.; Choua, S.; Collin, J.P.; Heinrich, M.; Bailly, C.; Karmazin-Brelot, L.; Bellemin-Laponnaz, S.; Dagorne, S. Redox and luminescent properties of robust and air-stable N-heterocyclic carbene group 4 metal complexes. Inorg. Chem. 2014, 53, 7371-7376. [CrossRef]

54. Quadri, C.C.; Le Roux, E. Copolymerization of cyclohexene oxide with $\mathrm{CO}_{2}$ catalyzed by tridentate N-heterocyclic carbene titanium(IV) complexes. Dalton Trans. 2014, 43, 4242-4246. [CrossRef] [PubMed]

55. Romain, C.; Miqueu, K.; Sotiropoulos, J.M.; Bellemin-Laponnaz, S.; Dagorne, S. Non-innocent behavior of a tridentate NHC chelating ligand coordinated onto a zirconium(IV) center. Angew. Chem. Int. Ed. 2010, 49, 2198-2201. [CrossRef] [PubMed]

56. Romain, C.; Specklin, D.; Miqueu, K.; Sotiropoulos, J.M.; Fliedel, C.; Bellemin-Laponnaz, S.; Dagorne, S. Unusual benzyl migration reactivity in NHC-bearing group 4 metal chelates: Synthesis, characterization, and mechanistic investigations. Organometallics 2015, 34, 4854-4863. [CrossRef]

57. Despagnet-Ayoub, E.; Takase, M.K.; Labinger, J.A.; Bercaw, J.E. Reversible 1,2-alkyl migration to carbene and ammonia activation in an N-heterocyclic carbene-zirconium complex. J. Am. Chem. Soc. 2015, 137, 10500-10503. [CrossRef] [PubMed]

58. Bellemin-Laponnaz, S.; Welter, R.; Brelot, L.; Dagorne, S. Synthesis and structure of V(V) and Mn(III) NHC complexes supported by a tridentate bis-aryloxide-N-heterocyclic carbene ligand. J. Organomet. Chem. 2009, 694, 604-606. [CrossRef]

59. Baltrun, M.; Watt, F.A.; Schoch, R.; Hohloch, S. Dioxo-, oxo-imido-, and bis-imido-molybdenum(VI) complexes with a bis-phenolate-NHC ligand. Organometallics 2019, 38, 3719-3729. [CrossRef]

60. Weinberg, D.R.; Hazari, N.; Labinger, J.A.; Bercaw, J.E. Iridium(I) and iridium(III) complexes supported by a diphenolate imidazolyl-carbene ligand. Organometallics 2010, 29, 89-100. [CrossRef]

61. Harris, C.F.; Bayless, M.B.; van Leest, N.P.; Bruch, Q.J.; Livesay, B.N.; Basca, J.; Hardcastle, K.I.; Shores, M.P.; de Bruin, B.; Soper, J.D. Redox-active bis(phenolate) N-heterocyclic carbene [OCO] pincer ligands support cobalt electron transfer series spannning four oxidation states. Inorg. Chem. 2017, 56, 12421-12435. [CrossRef]

62. Harris, C.F.; Kuehner, C.S.; Basca, J.; Soper, J.D. Photoinduced cobalt(III)-trifluoromethyl bond activation enables arene C-H trifluoromethylation. Angew. Chem. Int. Ed. 2018, 57, 1311-1315. [CrossRef] 
63. Borré, E.; Dahm, G.; Aliprandi, A.; Mauro, M.; Dagorne, S.; Bellemin-Laponnaz, S. Tridentate complexes of group 10 bearing bis-aryloxide N-heterocyclic carbene ligands: Synthesis, structural, spectroscopic, and computational characterization. Organometallics 2014, 33, 4374-4384. [CrossRef]

64. Romain, C.; Fliedel, C.; Bellemin-Laponnaz, S.; Dagorne, S. NHC bis-phenolate aluminium chelates: Synthesis, structure, and use in lactide and trimethylene carbonate polymerization. Organometallics 2014, 33, 5370-5379. [CrossRef]

65. Baltrun, M.; Watt, F.A.; Schoch, R.; Wölper, C.; Neuba, A.G.; Hohloch, S. A new bis-phenolate mesoionic carbene ligand for early transition metal chemistry. Dalton Trans. 2019, 48, 14611-14625. [CrossRef] [PubMed]

66. Arnold, P.L.; Rodden, M.; Davis, K.M.; Scarisbrick, A.C.; Blake, A.J.; Wilson, C. Asymmetric lithium(I) and copper(II) alkoxy- $N$-heterocyclic carbene complexes; crystallographic characterization and Lewis acid catalysis. Chem. Commun. 2004, 14, 1612-1613. [CrossRef] [PubMed]

67. Arnold, P.L.; Wilson, C. Sterically demanding bi- and tridentate alkoxy- $N$-heterocyclic carbenes. Inorg. Chim. Acta 2007, 360, 190-196. [CrossRef]

68. Arnold, P.L.; Casely, I.J.; Turner, Z.R.; Carmichael, C.D. Functionalized saturated-backbone carbene ligands: Yttrium and uranyl alkoxy-carbene complexes and bicyclic carbene-alcohol adducts. Chem. Eur. J. 2008, 14, 10415-10422. [CrossRef]

69. Arduengo, A.J., III; Dolpin, J.S.; Gurau, G.; Marshall, W.J.; Nelson, J.C.; Petrov, V.A.; Runyon, J.W. Synthesis and complexes of fluoroalkoxy carbenes. Angew. Chem. Int. Ed. 2013, 52, 5110-5114. [CrossRef]

70. Matsumura, N.; Kawano, J.I.; Fukunishi, N.; Inoue, H. Synthesis of new transition metal carbene complexes from $\pi$-sulfurane compounds: Reaction of 10-S-3 tetraazapentalene derivatives with $\mathrm{Pd}\left(\mathrm{PPh}_{3}\right)_{4}$ and $\mathrm{RhCl}\left(\mathrm{PPh}_{3}\right)_{3}$. J. Am. Chem. Soc. 1995, 117, 3623-3624. [CrossRef]

71. Iwasaki, F.; Manabe, N.; Nishiyama, H.; Takada, K.; Yasui, M.; Kusamiya, M.; Matsumura, N. Crystal and molecular structures of hypervalent thia/selena pentalenes. Bull. Chem. Soc. Jpn. 1997, 70, 1267-1275. [CrossRef]

72. Iwasaki, F.; Nishiyama, H.; Yasui, M.; Kusamiya, M.; Matsumura, N. Structures and formation mechanism of novel metal-carbene complexes derived from hypervalent thiadiselenadiazapentalenes. Bull. Chem. Soc. Jpn. 1997, 70, 1277-1287. [CrossRef]

73. Sellmann, D.; Allmann, C.; Heinemann, F.; Knoch, F.; Sutter, J. Ubergangsmetallkomplexe mit schwefelliganden CXXIV. J. Organomet. Chem. 1997, 541, 291-305. [CrossRef]

74. Spencer, L.P.; Winston, S.; Fryzuk, M.D. Tridentate amido carbene ligands in early-transition-metal coordination chemistry. Organometallics 2004, 23, 3372-3374. [CrossRef]

75. Spencer, L.P.; Fryzuk, M.D. Synthesis and reactivity of zirconium and hafnium complexes incorporating chelating diamido-N-heterocyclic-carbene ligands. J. Organomet. Chem. 2005, 690, 5788-5803. [CrossRef]

76. Spencer, L.P.; Beddie, C.; Hall, M.B.; Fryzuk, M.D. Synthesis, reactivity, and DFT studies of tantalum complexes incorporating diamido- $N$-heterocyclic carbene ligands. Facile endocyclic $\mathrm{C}-\mathrm{H}$ bond activation. J. Am. Chem. Soc. 2006, 128, 12531-12543. [CrossRef] [PubMed]

77. Liao, C.Y.; Chan, K.T.; Zeng, J.Y.; Hu, C.H.; Tu, C.Y.; Lee, H.M. Nonchelate and chelate complexes of palladium(II) with N-heterocyclic carbene ligands of amido functionality. Organometallics 2007, 26, 1692-1702. [CrossRef]

78. IUPAC. Compendium of Chemical Terminoly, 2nd ed.; (The Gold Book) Online Corrected Version $2006 \eta$ (eta or hapto) in Inorganic Nomenclature; McNaught, A.D., Wilkinson, A., Eds.; RSC: Cambridge, UK, 1997.

79. Schmidbaur, H. Phosphorus ylides in the coordination sphere of transition metals: An inventory. Angezw. Chem. Int. Ed. 1983, 22, 907-927. [CrossRef]

80. Chauvin, R.; Canac, Y. Late Transition Metals of Neutral $\eta^{1}$-Carbon Ligands; Springer: Berlin/Heidelberg, Germany, 2010; Volume 30, pp. 1-252.

81. Abdalilah, M.; Canac, Y.; Lepetit, C.; Chauvin, R. Towards the stability limit of cyclic diphosphonium bis-ylides. C. R. Chimie 2010, 3, 1091-1098. [CrossRef]

82. Canac, Y.; Duhayon, C.; Chauvin, R. A diaminocarbene-phosphonium ylide: Direct access to C,C-chelating ligands. Angew. Chem. Int. Ed. 2007, 46, 6313-6315. [CrossRef]

83. Abdellah, I.; Debono, N.; Canac, Y.; Duhayon, C.; Chauvin, R. Atropochiral (C,C)-chelating NHC-ylide ligands: Synthesis and resolution of palladium(II) complexes thereof. Dalton Trans. 2009, 35, 7196-7202. [CrossRef] 
84. Canac, Y.; Chauvin, R. Atropochiral C,X- and C,C-chelating carbon ligands. Eur. J. Inorg. Chem. 2010, 16, 2325-2335. [CrossRef]

85. Maaliki, C.; Abdalilah, M.; Barthes, C.; Duhayon, C.; Canac, Y.; Chauvin, R. Bis-ylide ligands from acyclic proximal diphosphonium precursors. Eur. J. Inorg. Chem. 2012, 2012, 4057-4064. [CrossRef]

86. Benaissa, I.; Taakili, R.; Lugan, N.; Canac, Y. A convenient access to N-phosphonio-substituted NHC metal complexes [M = Ag(I), Rh(I), Pd(II)]. Dalton Trans. 2017, 46, 12293-12305. [CrossRef] [PubMed]

87. Barthes, C.; Bijani, C.; Lugan, N.; Canac, Y. A palladium(II) complex of a $\mathrm{C}_{4}$ chelating bis(NHC) diphosphonium bis(ylide) ligand. Organometallics 2018, 37, 673-678. [CrossRef]

88. Taakili, R.; Lepetit, C.; Duhayon, C.; Valyaev, D.A.; Lugan, N.; Canac, Y. Palladium(II) pincer complexes of a C,C,C-NHC, diphosphonium bis(ylide) ligand. Dalton Trans. 2019, 48, 1709-1721. [CrossRef] [PubMed]

89. Canac, Y. Carbeniophosphines versus phosphoniocarbenes: The role of the positive charge. Chem. Asian. J. 2018, 13, 1872-1887. [CrossRef]

90. Despagnet-Ayoub, E.; Miqueu, K.; Sotiropoulos, J.M.; Henling, L.M.; Day, M.W.; Labinger, J.A.; Bercaw, J.E. Unexpected rearrangements in the synthesis of an unsymmetrical tridentate dianionic $N$-heterocyclic carbene. Chem. Sci. 2013, 4, 2117-2121. [CrossRef]

91. Despagnet-Ayoub, E.; Henling, L.M.; Labinger, J.A.; Bercaw, J.E. Group 4 transition-metal complexes of an aniline-carbene-phenol ligand. Organometallics 2013, 32, 2934-2938. [CrossRef]

92. Manabe, N.; Yasui, M.; Nishiyama, H.; Shimamoto, S.; Matsumura, N.; Iwasaki, F. Crystal and molecular structures of novel metal-carbene complexes IV. Effect of carbonyl groups and formation mechanism. Bull. Chem. Soc. Jpn. 1996, 69, 2771-2780. [CrossRef]

93. Taakili, R.; Barthes, C.; Goëffon, A.; Lepetit, C.; Duhayon, C.; Valyaev, D.A.; Canac, Y. NHC Core Phosphonium Ylide-based Palladium(II) Pincer Complexes: The Second Ylide Extremity Makes the Difference. Inorg. Chem. 2020. [CrossRef]

94. Canac, Y.; Lepetit, C.; Abdalilah, M.; Duhayon, C.; Chauvin, R. Diaminocarbene and phosphonium ylide ligands: A systematic comparison of their donor character. J. Am. Chem. Soc. 2008, 130, 8406-8413. [CrossRef]

95. Canac, Y.; Lepetit, C. Classification of the electronic properties of chelating ligands in $\operatorname{cis}-\left[\mathrm{LL}^{\prime} \mathrm{Rh}(\mathrm{CO})_{2}\right]$ complexes. Inorg. Chem. 2017, 56, 667-675. [CrossRef]

(C) 2020 by the authors. Licensee MDPI, Basel, Switzerland. This article is an open access article distributed under the terms and conditions of the Creative Commons Attribution (CC BY) license (http://creativecommons.org/licenses/by/4.0/). 